\title{
Next generation organoids for biomedical research and applications
}

\section{Lou, Yan-Ru}

2018

Lou , Y-R \& Leung , A W 2018 , ' Next generation organoids for biomedical research and applications ' , Biotechnology Advances , vol. 36 , no. 1 , pp. 132-149 . https://doi.org/10.1016/j.biotechadv.2017.10.

http://hdl.handle.net/10138/327408

https://doi.org/10.1016/j.biotechadv.2017.10.005

cc_by_nc_nd

acceptedVersion

Downloaded from Helda, University of Helsinki institutional repository.

This is an electronic reprint of the original article.

This reprint may differ from the original in pagination and typographic detail.

Please cite the original version. 


\section{Title}

2 Next Generation Organoids for Biomedical Research and Applications

3

4 Authors

5 Yan-Ru Lou ${ }^{1, *}$, Alan W. Leung ${ }^{2, *}$

6

iation

$8{ }^{1}$ Division of Pharmaceutical Biosciences, Faculty of Pharmacy, University of Helsinki, Helsinki, 9 Finland

$10{ }^{2}$ Yale Stem Cell Center and Department of Genetics, Yale School of Medicine, Yale University, 11 New Haven, Connecticut, United States

\section{* Correspondence}

14 Alan W. Leung, Yale Stem Cell Center and Department of Genetics, Yale School of Medicine, 15 Yale University, New Haven, Connecticut, United States

16 Email: alan.leung@yale.edu

17 Yan-Ru Lou, Division of Pharmaceutical Biosciences, Faculty of Pharmacy, University of 18 Helsinki, Helsinki, Finland

19 Email: yan-ru.lou@helsinki.fi 


\section{Abstract}

21 Organoids are in vitro cultures of miniature fetal or adult organ-like structures. Their potentials for use in tissue and organ replacement, disease modeling, toxicology studies, and drug discovery are tremendous. Currently, major challenges facing human organoid technology include (i) improving the range of cellular heterogeneity for a particular organoid system, (ii) mimicking the native micro- and matrix-environment encountered by cells within organoids, and (iii) developing robust protocols for the in vitro maturation of organoids that remain mostly fetallike in cultures. To tackle these challenges, we advocate the principle of reverse engineering that replicates the inner workings of in vivo systems with the goal of achieving functionality and maturation of the resulting organoid structures with the input of minimal intrinsic (cellular) and environmental (matrix and niche) constituents. Here, we present an overview of organoid technology development in several systems that employ cell materials derived from fetal and adult tissues and pluripotent stem cell cultures. We focus on key studies that exploit the selforganizing property of embryonic progenitors and the role of designer matrices and cell-free scaffolds in assisting organoid formation. We further explore the relationship between adult stem cells, niche factors, and other current developments that aim to enhance robust organoid maturation. From these works, we propose a standardized pipeline for the development of future protocols that would help generate more physiologically relevant human organoids for various biomedical applications.

\section{Keywords}

41 Organoids; Human; Reverse Engineering; Self-organization; Designer Matrix; Niche Factors; Pluripotent Stem Cells; Drug Screening; Disease Modeling; Transplantation 


\section{INTRODUCTION}

Strong predictability of preclinical testing is vital to success in clinical trials. Current preclinical tests for efficacy, toxicity, and pharmacokinetics are far from perfect. While animal models have been regarded as the gold standard, the use of laboratory animals continues to pose ethical questions. The considerable animal species differences in reactions to drugs (Burkina et al., 2017) and in disease phenotypes (Seok et al., 2013) also significantly lower the accuracy of preclinical predictions. For some diseases - such as infectious diseases - no relevant animal models are available. It has been reported that only $8 \%$ of the predictions of cancer drugs generated from animal models have been successfully translated into human clinical trials (Mak et al., 2014). In addition to animal models, in vitro two-dimensional (2D) cell cultures are also widely used for preclinical testing. The predictions from 2D cell cultures, however, are often difficult to interpret and could be misleading because cells cultured in 2D environments often lose their functionality and have altered phenotypes that are different from those in in vivo tissues and organs. In recent years, the United States Environmental Protection Agency (EPA), the National Institute of Health (NIH), and the Defense Advanced Research Projects Agency (DARPA) have initiated programs such as the ToxCast Programme and the Microphysiological Systems (MPS) Program to advocate the development of human cellular models to assess the safety and/or the efficacy of environmental chemicals (Kleinstreuer et al., 2014) and drugs (Fabre et al., 2014). In particular, the DARPA MPS program promotes the development of organs-on-chips and human-on-chips approaches to synthesize in vitro three-dimensional (3D) human tissues derived from cultured cells on bioengineered platforms to bring together nativelike tissue architecture and physiology for highly-predictive and physiologically-relevant monitoring of the functions and effects of toxic substances and drugs at the organ- or body-levels. There is an urgent need to develop more physiologically relevant, efficient, and robust protocols to advance technology that synthesizes human tissues.

1.1 DEFINING ORGANOIDS. The term organoid was first employed in an oncology study to indicate a pathological and tumor-like tissue mass formed in a human infant (Kretzschmar and Clevers, 2016; Smith and Cochrane, 1946). The term has since been used in the medical field to describe a multisystem disorder, called organoid nevus syndrome, related to benign outgrowths of sebaceous glands on the skin and the eye of affected individuals (Shields et al., 1996). Organoid was loosely used in experiments to denote transplanted tissues or the resultant tissue masses from transplants (Waddell, 1949; Yoshida et al., 1980). Increasingly frequent in the late 1980s and early 1990s, organoid was employed in developmental biology experiments to denote high-density or organ-like cultures generated through aggregation and cell sorting of dissociated animal cells and tissues (Elkasaby et al., 1991; Ridgeway et al., 1986; Schroter-Kermani et al., 1991). The two decades following this were characterized by the advent of embryonic (ESC) and induced pluripotent (iPSC) stem cell cultures derived from rodent, primate, and human embryos (Martin, 1980; Thomson et al., 1998; Thomson et al., 1995) and somatic cells (Takahashi et al., 2007; Takahashi and Yamanaka, 2006; Wernig et al., 2007; Yu et al., 2007), as well as the discovery of adult stem cells in various tissues including retina (Tropepe et al., 2000), bone marrow (Wilson and Trumpp, 2006), epidermis (Clayton et al., 2007), intestinal crypts (Clevers, 2013), stomach glands (Leushacke et al., 2013), testis (Klein et al., 2010), esophagus (Doupe et al., 2012), and brain (Fuentealba et al., 2012). Following these successive breakthroughs, the definition of organoid evolved to describe the in vitro $3 \mathrm{D}$ structures derived from differentiating cultures of ESCs, iPSCs, or adult stem cells that bear an in vivo tissue-like arrangement, compartmentalization, and functionality. In this review, we adopt 
this definition and will use the term organoids to describe the in vitro cultures of conglomerates of tissue-specific cells that incorporate cell-cell and cell-matrix interactions in an orderly and 3D manner. In most cases described here, organoids were cultured either in suspension or embedded in animal-derived matrices such as Matrigel. Organoids can be generated from clonal derivatives of adult stem cells or aggregates of stem cells and organ-specific progenitors derived from primary embryonic cell types, ESCs, or iPSCs. In regular cultures, depending on the types of organs, organoids can be spherical or irregularly shaped masses ranging in diameter from 0.1 to $1 \mathrm{~mm}$. They demonstrate significant homology in terms of tissue architecture and gene expression profiles compared to their in vivo counterparts. They also display growth, undergo morphogenesis, mature, and in many cases, exhibit functionality similar to their tissues of origin and have the ability to integrate into embryonic and adult tissues upon transplantation.

\subsection{MAJOR TRENDS AND CHALLENGES IN CURRENT ORGANOID RESEARCH.} Studies involving organoid generation have rapidly evolved in recent years, branching into a field going into multiple directions. There are studies using organoids to understand the pathology of a number of genetic disorders including cystic fibrosis (Dekkers et al., 2013; Hohwieler et al., 2017), polycystic kidney disease (Freedman et al., 2015), Hirschsprung's disease (Workman et al., 2017), and neurodevelopmental defects like microcephaly and lissencephaly (Bershteyn et al., 2017; Lancaster et al., 2013). Organoid-driven approaches have been employed to investigate disease mechanisms of infectious pathogens like Helicobacter (McCracken et al., 2014) and Zika virus (Cugola et al., 2016; Dang et al., 2016; Garcez et al., 2016; Li et al., 2017; Qian et al., 2016). Not surprisingly, organoids derived from intestinal and hepatic cell types have been examined as a possible source of in vitro tissues for regenerative medicine, and these studies have been met with great success in numerous animal models (Fordham et al., 2013; Fukuda et al., 2014; Huch et al., 2015; Takebe et al., 2014; Yui et al., 2012). More recently, toxicology screens (Schwartz et al., 2015; Takasato et al., 2015) and studies on patient-specific genetic factors and drug responses in tumorigenesis have begun employing organoid technology (Cristobal et al., 2017; Fujii et al., 2016; Li et al., 2014; Matano et al., 2015; van de Wetering et al., 2015; Verissimo et al., 2016; Weeber et al., 2015).

ESCs, iPSCs, and, to a certain extent, adult stem cells provide a virtually unlimited source of raw cellular materials for organoid generation. In the case of ESCs and iPSCs, organoids are derived either via the embryoid body method, in which pluripotent stem cell colonies are lifted up from undifferentiated adherent cultures and fragmented into small pieces for further differentiation (Freedman et al., 2015; Kadoshima et al., 2013; Lancaster and Knoblich, 2014; Lancaster et al., 2013; Muguruma et al., 2015; Nakano et al., 2012; Suga et al., 2011) or directly from sub-structures formed on differentiating adherent cultures (CalderonGierszal and Prins, 2015; Dye et al., 2015; McCracken et al., 2014). Despite these advances in technique, there are still tissues that are recalcitrant to organoid derivation such as the epidermis, the testes, the ovaries, the bladder, the thyroid gland, and other non-epithelial tissues such as the heart and the skeletal muscles (Fatehullah et al., 2016). Additional challenges demand improvements to current organoid technology. Organoid derivation often results from the tedious and unguided testing of empirical conditions for proper differentiation, yielding a long and costly generation process. Heterogeneity in viability, size, and shape of the derived organoids plagues the development of high throughput systems and algorithms that can be employed for phenotypic, toxicologic, and drug screens. In many cases, techniques used for generating one type of organoid cannot be easily transferred to a different organoid system, e.g. the procedures in developing a brain organoid will bear little resemblance to those for a liver organoid. This lack 
of transferability of organoid techniques across systems hinders the development of the organoid field and limits its potential to incorporate other fields of study such as computational science and bioengineering that require the building of mathematical/engineering models and the incorporation of scalable and cross-system parameters. Importantly, organoids usually lack the co-induction of the essential cell types and the associated extracellular matrices and native microenvironment that will allow the recapitulation of the in vivo tissue sizes, structures, organization, inter-cellular communication, and functionality. Lastly, very little is known about the culturing conditions and specific factors driving the in vitro maturation of organoids, which in many cases remain fetal in nature.

\subsection{APPLYING THE CONCEPT OF REVERSE ENGINEERING TO ORGANOID} GENERATION. In biology, reverse engineering is the process of extracting the minimal set of design parameters from existing biological systems for creating a functional mimicry (Ingber, 2016; Shinozawa et al., 2016). Design parameters may include cell type, soluble microenvironment, insoluble microenvironment, and physical parameters such as shape, external force, and fluid flow. We propose that by employing the principle of reverse engineering, we can solve some of these issues, in particular: (i) recapitulating the in vivo cellular heterogeneity in organoid systems, (ii) controlling the organoid microenvironments including extracellular matrix (ECM) composition, stiffness, and architecture, and (iii) promoting the in vitro maturation of organoids. Here, we review current developments and techniques concerning the generation of human organoids and propose that by studying and employing the minimal elements required for the different stages of in vitro organoid synthesis and maturation, we can improve and streamline current organoid generation approaches as depicted in Figure 1.

\section{EXPLOITING THE SELF-ORGANIZING PROPERTY OF EMBRYONIC PROGENITORS}

Self-organization has been widely demonstrated in animal studies, whereby tissuespecific progenitors, after random dispersal, aggregate, sort, and organize to reform a 3D tissue mass closely resembling the organs and tissues where the cell types belong (Takeichi, 2011). Recent ESC and iPSC studies have exploited this fundamental cellular principle. Selforganization is a process involving the self-assembly of dissociated cells and the subsequent reorganization into tissue-like structures. Using this approach, termed "dissociation-aggregation approach", cell progenitors from different lineages can be recombined to form in vitro organoids with improved representation of cellular heterogeneity and interactions. In this section, we present a historical overview of the discovery of the self-organizing property of animal progenitors and summarize recent works in human organoids generated based upon this principle. We also review and propose studies by which the self-organizing process could be monitored and regulated.

2.1 REGENERATIVE POTENTIAL OF DISSOCIATED CELLS FROM ANIMAL EMBRYONIC TISSUES AND ORGANS.

2.1.1 Pioneering Experiments in Sponges and Hydroids. In the first series of experiments conducted over a century ago, Henry van Peters Wilson showed that sponges broken down into randomly dispersed single cells were able to reorganize into live sponges (Wilson, 1907). Similar results, detailing the generation of live hydranths, were found in a study performed by Charles Wesley Hargitt (Hargitt, 1915). A similar conclusion was drawn with some essential differences by a later study performed by De Morgan and Drew using different species. In their experiments, the resulting tissue aggregates, or restitution mass, developed the 
characterized tissue and cellular architecture of hydranths, e.g. well defined endodermal tubules, the outer perisarc, and the interstitial ectodermal cells, but soon underwent partial disintegration and were never able to give rise to live hydranths (De Morgan and Drew, 1914). Despite these differences, these early experiments sparked enormous interest in the regenerative ability of animal tissues and clearly demonstrated that dissociated cells carried the potential to reform tissues and structures. Tissue cells from different cellular origins, e.g. ectoderm and endoderm, also possessed the ability to attach to one another and undergo cellular rearrangements to achieve an advanced tissue morphology and architecture resembling those found endogenously. Interestingly, Wilson also found that cells from different species of sponges sorted out from each other and only recombined with cells of their own species (Wilson, 1907). This principle is not strictly adhered to in vertebrate cells where chimeric tissues and organs of different species origin could quite frequently be generated.

2.1.2 Regenerative Potential of Embryonic Tissues in Other Animal Species. Following this initial discovery, there remained an important question of whether animal cells generally possess a similar self-organizing ability. Testing of this hypothesis was not feasible until the early 1940s when Johannes Holtfreter discovered a way to conveniently dissociate and reassociate Xenopus frog embryonic cells by exploiting the changes in cell adhesion of frog cells to changes in environmental pH (Steinberg and Gilbert, 2004). Thereafter, Aaron Moscona and colleagues employed trypsin, at the time a novel enzymatic tool, for more efficient cell dissociation in avian and mammalian organs and tissues (Moscona, 1957b; Moscona and Moscona, 1952). Culturing conditions for the resultant tissue aggregates however posed additional requirements for more finely regulated nutrient and thermal conditions. This led to the development of more sophisticated culture media and increased precision on the controls for $\mathrm{pH}$ and heating to promote prolonged maintenance of tissue masses in vitro.

Other advances in culturing techniques such as the advent of rotation cultures (Moscona, 1961) and the use of chorioallantoic membrane as an incubator for organoid tissues (Garber and Moscona, 1964) had facilitated widespread employment of the dissociation-aggregation method and had advanced cellular differentiation of the resulting organoids. Rotation cultures, for instance, involved incubation of trypsin-dissociated cell suspension in a swirling flask, assisting single cells to collide, adhere, and form cell aggregates. It had been used to form mouse embryonic brain cell aggregates displaying a high degree of cellular organization (DeLong, 1970), undergoing the regular biochemical differentiation and expressing enzymes responsible for neural transmission (Seeds, 1971), forming myelination of axons and displaying signs of proliferation and synapse formation (Seeds and Vatter, 1971). Due to concerns that the aggregative features observed in dissociated embryonic cells was an artificial phenomenon created by in vitro cultures, a series of studies were carried out aiming to test if dissociated cells could aggregate in an embryonic environment such as the chorioallantoic membrane. In those cases, dissociated embryonic kidney, liver, and skin cells were tested and successfully differentiated as aggregates (Garber et al., 1968; Garber and Moscona, 1964; Weiss and Taylor, 1960).

In another classic embryological experiment, epidermis and neural tube from early amphibian embryos were dissociated and allowed to re-aggregate (Townes and Holtfreter, 1955). The two cell populations sorted out from each other and self-organized into epidermal cells covering the outside of the tissue aggregate containing a neural tube-like structure. Interestingly, there were other studies producing chimeric organoid structures with different animal species or even organs with little relation to each other under normal developmental contexts. For instance, 
chimeric experiments were carried out for chick nephrogenic and mouse chondrogenic cells; ultimately concluding that the nephrogenic and chondrogenic cells aggregate according to their tissue types, but disregard their species-specificity (Moscona, 1957a). In another study, mouse skin cells at an advanced stage were found to suppress feather formation in chick-mouse chimeric aggregates, while mouse skin cells from a younger stage appeared to incorporate into the feather structures (Garber et al., 1968). Further, chimeric aggregates of human and mouse cells derived from the same organs (lung, liver, and brain) integrated well with each othersimilar to those derived from the same species - suggesting that, between human and mouse, tissue specificity dominates over species specificity (Cassiman and Bernfield, 1974). A similar phenomenon was observed for embryonic chick and rat heart cells, in which chimeric aggregates were formed (Nag et al., 1980). These experiments highlighted the versatility and flexibility of the embryonic and fetal progenitors in chimeric species organ synthesis and inspired more recent experiments that employed the successful integration of embryonic progenitors derived from ESC and iPSC cultures in animal transplantation as a readout for functionality (e.g. Cohen et al., 2016).

2.1.3 Recent Development Using Dissociated Embryonic Progenitors for Organoid Generation. Over the past four to five decades, numerous experiments have continuously demonstrated the tremendous propensity of embryonic and fetal progenitors to self-renew, differentiate, self-organize, and regenerate. In particular, organoid structures have been generated from aggregating embryonic and fetal progenitors derived from virtually all types of embryonic organs and tissues from higher vertebrates including those that are ectoderm (brain, spinal cord, inner ear, submandibular gland, retina, lens), mesoderm (heart, limb bud, kidney), and endoderm (lung, pancreas, liver) derived (Table 1). In one particular example, fragments and aggregates of dissociated cells of embryonic day 13 mouse submandibular gland epithelium were able to selforganize and undergo branching morphogenesis, forming tissues with structural features and differentiation markers characteristic of the intact gland. The study also reported that the selforganization process was sensitive to perturbation by integrin and E-cadherin signaling (Wei et al., 2007). In another well-studied example, dissociated embryonic chick retina cells in rotation cultures were able to reconstitute all the essential retinal layers including differentiating cone and rod cells aligned in rosette structures within the tissue aggregates. These tissue aggregates, socalled rosette spheres, could reach a size of $0.3-0.5 \mathrm{~mm}$ and included up to half a million cells. The tissue organization of these rosette spheres was further improved by the inclusion of the retinal pigmented epithelium, which promoted laminar reconstitution and the proper alignment of the different retinal layers (Layer et al., 2001). Many current studies have shifted their focus from simple aggregation experiments to a number of different directions including investigating (1) the identity of the soluble intercellular factors and the intracellular molecular mechanisms that promote the aggregation and the subsequent cell-sorting processes, (2) the role of developmental ages of embryonic and fetal progenitors in organoid formation, (3) the effects of specific dissociation techniques, and (4) the functionality of the resulting tissue aggregates or organoids with more sophisticated biochemical and morphological studies as readouts for function. Documenting these studies is out of the scope of this review, but some of them have been summarized and discussed (Takeichi, 2011). 


\subsection{AGGREGATION EXPERIMENTS EMPLOYING CELL PROGENITORS DERIVED FROM PLURIPOTENT STEM CELLS.}

Given these strong data in animal works and the rich resources of efficient adherent differentiation protocols, recent studies have started to employ dissociated embryonic cell types derived from human ESCs and iPSCs as raw materials for organoid generation. In these studies, ESC and iPSC colonies were differentiated either directly as colonies or after a re-plating step as a monolayer of evenly spread-out, single cells. These differentiating adherent cultures, after reaching the progenitor stages of their respective lineages, were dissociated, dispersed, and reaggregated to form suspension 3D organoids. In some cases, organoids were derived from progenitors of single germ layers, like in the case of pancreatic (Hohwieler et al., 2017; Kim et al., 2016) and kidney organoids (Takasato et al., 2016; Takasato et al., 2015). In other cases, composite organoids were made from progenitors of multiple germ layer lineages such as liver, cerebral cortical, and intestinal organoids (Schwartz et al., 2015; Shinozawa et al., 2016; Takebe et al., 2013; Takebe et al., 2014; Workman et al., 2017). Many of these organoids have been successfully employed in toxicology studies, disease modeling, and animal transplantation studies. Timed addition of progenitor cell types to composite organoids has allowed increased control over the timing and incorporation of specific cell-cell interactions during organoid generation and differentiation to mimic in vivo situations. Cryopreservation of progenitor cell types for these organoids has been successfully performed, thus permitting a consistent and convenient supply of progenitors for organoid formation.

2.2.1 Organoids Derived from Single Germ Layers. KIDNEY. Mammalian kidneys are derived from the intermediate mesoderm that gives rise to the major kidney progenitors including the ureteric epithelium, metanephric mesenchyme, and the renal stroma. Ureteric epithelium forms the collecting tubes whereas the metanephric mesenchyme forms the nephrons, which include substructures like the proximal and distal tubules and the glomeruli. The mature kidney epithelial structures are surrounded by a renal interstitium containing a vascular network derived from the renal stroma. To generate kidney progenitors, human ESCs were differentiated from the primitive streak stage to form $\mathrm{PAX} 2^{+} \mathrm{LHX} 2^{+}$intermediate mesoderm by manipulation of WNT and FGF signaling (Takasato et al., 2014). Differentiating embryonic kidney cells, resulting from the further differentiation of $\mathrm{PAX}_{2}^{+} \mathrm{LHX}_{2}{ }^{+}$intermediate mesoderm progenitors, were dispersed and aggregated to form organoid structures that displayed evidence of development of the ureteric epithelium, the proximal tubules, and the renal vesicles. However, no definitive nephron structures could be identified in these organoids. In a subsequent study, by manipulating the strength and the duration of retinoic acid and WNT signaling, the same group identified a way to preferentially induce ureteric epithelium development over metanephric mesenchyme (Takasato et al., 2016; Takasato et al., 2015). By dissociating progenitors at an earlier time point (day 6 instead of day 18) and optimizing WNT and FGF signaling postorganoid formation, kidney organoids matured to form nephron-like structures including the essential components of collecting ducts, distal and proximal tubules, and glomeruli. Endothelial vascular networks, together with pericyte-like and mesangial-like cells, were also identified and appeared to invade some of the glomeruli. Advanced morphological patterning in terms of the arrangement of the collecting ducts to nephron-like structures and the presence of cortical versus medullary stroma patterning indicated the formation of a complex kidney-like structure. Furthermore, these organoids were tested positive for endocytic function to dextran and for response to nephrotoxic agents like Cisplatin. Comparisons to a range of human fetal tissues 
suggested that these kidney organoids resembled first trimester kidney tissues suggestive of their fetal nature and the need for further maturation.

$\boldsymbol{P A N C R E A S}$. The pancreas is a glandular organ, which serves dual functions in regulating blood sugar level, by its exocrine glands that secrete insulin and glucagon and in digesting proteins, lipids, carbohydrate, and nucleic acids by excreting enzymes from its endocrine glands. Exocrine (Hohwieler et al., 2017) and endocrine (Kim et al., 2016) pancreatic progenitors have been respectively derived from human ESC and iPSC 2D cultures. These cultures were dissociated and re-aggregated in suspension to form functional and transplantable endocrine and exocrine organoids. Both endocrine and exocrine pancreatic progenitors were differentiated from ESCs and iPSCs via activation of WNT and Activin signaling to prompt a definitive endoderm fate, followed by treatment with retinoid acid, FGF ligand, and BMP inhibitor to generate $\mathrm{PDX}^{+}$pancreatic endoderm, a common progenitor for endocrine and exocrine cell types. $\mathrm{PDX}^{+}$cells were then skewed towards either exocrine or endocrine progenitors using distinct growth factor and small molecule cocktails.

Pancreatic endocrine cells expressed proprotein convertase $1 / 3$, glucose transporter 1 , and the majority of pancreatic hormones such as insulin, somatostatin, and pancreatic peptide, with the exception of glucagon (Kim et al., 2016). Detailed marker profiling, however, suggested that these endocrine cells were still immature. For instance, the authors observed a low expression level of mature $\beta$-cell marker NKX6-1 and the coexpression of endocrine progenitor marker MAFB with insulin, indicating that the endocrine cells derived were immature. Upon organoid formation by aggregation of endocrine cells, these cells continued to express pancreatic hormones and the above mentioned functional markers, but, in addition, lost expression of MAFB in insulin ${ }^{+}$cells, gained expression of the mature $\beta$-cell marker MAFA (Nishimura et al., 2006), and increased expression of glucose sensor genes (SLC2A1 and GCK). All these were indicative of improved $\beta$-cell function and maturation. Further, these pancreatic endocrine organoids displayed sensitivity to high glucose concentration and responded by inducing insulin and c-peptide secretion. Functionally, transplantation of pancreatic endocrine organoids prolonged the life span of streptozotocin treated mice, which had their pancreatic islet destroyed by streptozotocin treatment. The mice with organoid transplants displayed a response to high blood glucose and expressed at least one endocrine hormone, c-peptide, in the blood stream. Function of the transplants however gradually became unstable after 2 weeks. Mice survived more than 40 days, but a more long-term survival study was not conducted and ultimate cause of transplant failure was not concluded.

In contrast to endocrine organoids, human pancreatic exocrine organoids formed by aggregation of dissociated exocrine cells contained acinar-like and ductal-like cell types and structures (Hohwieler et al., 2017). Activities for key exocrine enzymes such as carbonic anhydrase, amylase, trypsin, and elastase were detected. Cystic fibrosis patients display increased probability of pancreatitis, pancreatic exocrine insufficiency, and pancreatic cancer. Patient iPSCs carrying $C F T R^{a}$ mutations were used to derive pancreatic exocrine organoids for modeling cystic fibrosis disease progression. Forskolin is known to induce rapid swelling of control intestinal organoids but not in organoids derived from a cystic fibrosis mouse model

\footnotetext{
${ }^{\mathrm{a} C y s t i c}$ fibrosis transmembrane conductance regulator $(C F T R)$, the gene mutated in cystic fibrosis, encodes a chloride channel protein, a member of ATP-binding cassette transporter superfamily. CFTR mediates fluid homeostasis in the epithelia of organs such as pancreas, liver, intestine, and lung.
} 
(Dekkers et al., 2013). Expectedly, forskolin/IBMX treatment ${ }^{\mathrm{b}}$ did not induce much swelling in the lumens of human cystic fibrosis patient-derived organoids. Encouragingly, the swelling defect could be ameliorated in a pre-selected set of CFTR correctors and potentiators with known functions in improving CFTR activity, or with chemically modified CFTR mRNA that confers high stability and low immunogenicity, demonstrating a proof of principle for these organoids in disease modeling and compound screening. However, upon orthotopic transplantation to a mouse host, the human organoids remained fetal in gene expression, and, because of a lack of functional assays, it was difficult to assess the maturity and purity of the resulting human grafts.

2.2.2 Germ Layer Composite Organoids. INTESTINAL SYSTEM. Attention has often been paid to parenchymal cells in organoid generation. The role of non-parenchymal cells, such as neural cells, mesenchymal cells, and vascular cells, has been well documented in development and tissue functionality (Cleaver and Melton, 2003; Furness, 2012). A recent study, which appreciates the inclusion of these non-parenchymal cell types, generated human intestinal organoids with an intact enteric nervous system (Workman et al., 2017). In this study, dissociated caudal neural crest cells were recombined with human intestinal organoids by low speed centrifugation. Neuronal and glial differentiation was observed in intestinal organoids seeded with neural crest cells. The overall spatial relationship of the resulting composite organoid resembled human fetal or mouse embryonic day 11.5 intestine. These organoids were cultured in vitro for 28 days before transplantation. Importantly, the graft displayed neuronal calcium oscillations, contractile activity, and neuromuscular coupling suggestive of a functional enteric nervous system. These grafts were also used to model the phenotype of $P H O X 2 B$ mutations in the etiology of Hirschsprung's disease, a genetic disorder resulting in agangliogenesis of the human bowel.

LIVER. Hepatocytes are the major cell type in the liver, which make up around $80 \%$ of the parenchymal mass in the adult organ and display both endocrine and exocrine properties (SiTayeb et al., 2010; Zhao and Duncan, 2005). Non-hepatocyte cell types such as cholangiocytes, sinusoidal endothelial cells, Ito cells (hepatic stellate cells), Kupffer cells (tissue macrophages), and pit cells (natural killer cells) constitute the rest of the liver. The liver buds, which are derived from the foregut endoderm and containing the adult liver progenitors, are formed around embryonic day 8.5 in mouse. At embryonic day 9.5, hepatoblasts delaminate from the liver buds to invade the surrounding septum transversum (mesoderm derived), which contains progenitors for non-hepatocyte cell types such as Ito cells and endothelial cells. To recapitulate the in vivo cellular heterogeneity of adult liver and to promote the vascularization that is essential for normal liver function and transplantation, Takebe et al. attempted to generate in vitro human liver buds by aggregating cell types from two germ layer lineages: hepatic endoderm derived from ESC/iPSC cultures, and from the mesoderm, umbilical vein endothelial cells and mesenchymal stem cells (Takebe et al., 2013; Takebe et al., 2014). A 10: 7: 2 ratio of human $\mathrm{HNF}_{4} \mathrm{~A}^{+}$hepatic endoderm, umbilical vein endothelial cells, and mesenchymal stem cells were mixed and resuspended in hepatocyte culture medium. The cells in the suspension aggregated and self-organized to form liver-bud organoids containing an endothelial network and maturing hepatocytes with increased expression of early liver specific genes like alpha-fetoprotein, retinol binding protein 4, transthyretin, and albumin. Microarray analyses suggest that the resulting

\footnotetext{
${ }^{\mathrm{b}}$ Forskolin increases the amount of intracellular cAMP, which in turn activates CFTR that mediates fluid secretion into the lumen of small intestinal organoids. IBMX (3-isobutyl-1-methylxanthine) is a phosphodiesterase inhibitor. Because of its effect in inhibiting phosphodiesterase, IBMX may potentiate the accumulation of intracellular cAMP by the action of forskolin.
} 
liver-bud organoids resembled early embryonic liver buds in mouse (embryonic day 10.5 to 11.5). Upon transplantation into mouse brain, connectivity with host vasculatures was quickly observed. Prolonged cultures of transplants up to 60 days led to development of hepatic cord-like structures, which contained cells expressing tight junction proteins and collagens that are normally found along the entire length of the liver sinusoids. Albumin production by day 45 of transplantation was comparable to or surpassed in vitro cultures of adult human hepatocytes. Ketoprofen $^{\mathrm{c}}$ and debrisoquine ${ }^{\mathrm{d}}$ were used to distinguish human hepatic metabolic functions from mouse hepatic functions since these drugs are metabolized differently in human and mouse livers. Human specific metabolites, upon challenge with ketoprofen or debrisoquine, were found in the transplanted mouse blood serum and urine, suggestive of the presence of functional human liver tissues in the organoids. An additional minimally-invasive mesenteric transplantation model was carried out and the transplanted liver buds promoted survival of mice with ganciclovir-induced liver failure by $\sim 50 \%$ at day 30 after transplantation. No specific markers or assays however were used to detect the presence of other non-hepatocyte cell types either under in vitro cultures or upon transplantation. These non-hepatocyte cell types play important roles in liver function and pathology. Cholangiocytes, for example, are important for bile metabolism and hepatocyte survival and have been successfully derived from human iPSC cultures (Dianat et al., 2014). For other non-hepatocyte cell types, such as pit cells and Kupffer cells, there are no existing differentiation protocols.

CENTRAL NERVOUS SYSTEM. To mimic in vivo brain development, neural constructs (organoids) were generated by aggregating dissociated neural progenitors, mesenchymal stem cells, endothelial cells, and microglial/macrophage precursors (Schwartz et al., 2015). Neural constructs were formed with neural progenitors embedded in polyethylene glycol hydrogels, followed by seeding of endothelial cells and mesenchymal stem cells at day 9 and lastly with microglial/macrophage precursors at day 13 to mimic the in vivo recruiting sequence of blood vessels and macrophage after the formation of the neural tube. Timed addition of cell precursors to the initial neural constructs allowed temporal control of the incorporation of different cell types. The resultant neural organoids bore gene signatures for forebrain and hindbrain development and displayed markers for GABAnergic neurons, glutamatergic neurons, and glia. Extensive vascular networks and phagocytic activities were observed in the neural organoids suggestive of functional vascular and macrophage cell types. Machine learning refers to studying and developing algorithms that can iteratively learn from data without being explicitly programmed and make predictions. The neural organoids were employed for machine learning using RNA sequencing datasets with known neurotoxins and control compounds. Subsequent blind trials found that toxicity of 9 out of 10 known compounds could be correctly predicted suggesting that such neural organoids could be used for in vitro drug toxicity screens, although the authors admitted that a functional perfused blood-brain barrier could further improve predictability of drug toxicity. The blood-brain barrier is lined by specialized endothelial cells, called brain microvascular endothelial cells that regulate the transport of substances into and out of the brain. To reconstruct a functional adult-like blood-brain barrier, additional cell types are required, such as pericytes and brain microvascular endothelial cells

\footnotetext{
${ }^{c}$ Ketoprofen is primarily metabolized to ketoprofen-glucuronide by human hepatocytes and metabolized to hydroxyl-ketoprofen by mouse hepatocytes.

${ }^{\mathrm{d}}$ Debrisoquine is metabolized to 4-hydroxy debrisoquine by CYP2D6 in human hepatocytes. Mouse liver lacks 4-hydroxylase activity and thus cannot convert debrisoquine into its 4-hydroxy metabolite.
} 
(Lippmann et al., 2013). These cell types have been derived from human ESC and iPSC cultures (Lippmann et al., 2012; Orlova et al., 2014).

\subsubsection{Monitoring and Regulating the Self-organization Process to Facilitate Organoid} Formation. We envisage more widespread usage of the dissociation-aggregation method in future studies, especially for organ systems whose full functionality depends on the incorporation of multiple germ layer lineages. To improve this method, we propose timed and sequential incorporation of tissue- and organ-specific cell progenitors to better mimic the events occurring during embryonic development (Figure 2). Self-organization of the aggregating cells during organoid formation can be broken down into steps of temporally-overlapping and interrelated processes that could be monitored and regulated. These include the chemotactic movement of the aggregating cells (Chen et al., 2007), the cell surface interactions to matrices and to neighboring cells (Takebe et al., 2015), the cell-sorting process, the formation of the apical-basal orientation of individual cells, and the process of lumenogenesis (Odenwald et al., 2017; Taniguchi et al., 2015) (Figure 3). Time-lapse imaging of aggregating cell populations labeled transiently with fluorescent dyes or permanently with genetically-engineered reporters could allow tracking of the kinetics of organoid formation, whether they form under certain conditions or not, and, if they do form, how fast they form, and the dynamic changes of their shape along the time course of their formation. The speed of condensation and the changes in the shape of the forming organoids could be monitored by quantitative analyses (Takebe et al., 2015). Additionally, pharmacological interventions can be applied to regulate the speed of aggregation. Takebe et al. found that manipulation of myosin II activity controlled the collective movement of cells during the aggregation process (Takebe et al., 2015). Mesenchymal stem cells within the initial aggregating mix were identified as a key cell population that was essential to drive the aggregating process (Takebe et al., 2015). By closely monitoring the structural parameters of the forming organoids, such as their diameter and morphology, Arora and colleagues were able to promote the yield of successful intestinal organoids using an automated micro-peptide aspiration and release system (Arora et al., 2017). More studies in these areas are urgently needed to translate findings from organoid monitoring into promoting the successful formation of organoids.

\section{UTILIZING DESIGNER MATRICES AND SCAFFOLDS FOR ORGANOID FORMATION}

3.1 DESIGNER MATRICES AND MATRIX PARAMETERS. When considering the minimal elements for forming a functional organ or tissue, one must consider not only parenchymal cells and the less-represented and essential cell types like immune, vascular, and neural cells, but also the secreted ECM framework and its associated growth factors, cell interacting molecules, enzymes, and extracellular vesicles that produce the necessary physical and biochemical signals to support organ and tissue maintenance, growth, and morphogenesis. To mimic the physical and biochemical properties of in vivo cellular microenvironment, designer matrices (Gjorevski et al., 2014), either derived from natural sources or artificially synthesized with physical and biochemical properties specially designed for a certain cell type can be employed. Controls exercising on organoid formation can be greatly facilitated by incorporating designer matrices. For example, micropores present in hydrogels and scaffolds would allow organoid formation at a defined shape and size. The physical and biochemical properties of designer matrices can be spatially and/or temporally controlled to enable stem cells to selforganize, and this topic has been elegantly reviewed (Gjorevski et al., 2014). Together with 
advanced 3D printing technology, studies can be conducted to fabricate designer matrices with controlled nano- and micro-structures to standardize and improve organoid formation. We propose that by studying the endogenous composition and dynamics of ECM expression during the development of animal and human organs and tissues and empirically testing the requirements of these ECM and other tailor-made matrices in in vitro cultures, one would be able to determine the minimal and essential elements and signals from the ECM that are required for the cellular activity, organization, and differentiation of organoid cultures.

A number of parameters dictate the ability of matrices to modulate organoid formation. These parameters include stiffness, composition, topology (or geometry), degradability, the ability to bind growth factors, and the capacity to modulate growth factor activities. Regulating these parameters may prove advantageous to promoting organoid formation, standardizing organoid production, and moving organoid technology to clinics. Organoids are currently cultured either matrix-free or by embedding them in matrices like Matrigel. Matrix-free suspension organoid cultures display superb nutrient diffusion, but lack certain physicochemical supports, resulting in organoids that may clump and causing lower yields, and may develop necrosis within the core. Matrix provides an initial guidance to the aggregating cells and serves as a subsequent physical support and constraint for organoid formation. Matrigel and collagen type I are the most commonly used matrices in organoid cultures derived from ESCs, iPSCs, and adult stem cells. However, there are few studies investigating the precise roles of these matrices in supporting organoid formation. On top of this, the animal origin and lot-to-lot variation of Matrigel hinders the use of the derived organoids in clinical applications. Fully synthetic or recombinant matrices are chemically defined and can be standardized for organoid production and better facilitate downstream clinical applications. Well-defined matrices, such as those incorporating synthetic ECM peptides with artificial hydrogels, allow precise control of the cellular microenvironments.

Matrix stiffness is an important parameter regulating cell behavior. Matrix stiffness reflects the resistance that a cell experiences when it deforms the matrix, and it can be measured by the elastic constant (Young's modulus, presented as Pascal). Cells sense matrix stiffness through mechanoreceptors, such as integrins (Humphrey et al., 2014). It was found that a stiffer hydrogel $(1.3 \mathrm{kPa})$ supported intestinal stem cell expansion, whereas softer hydrogel (approximately $190 \mathrm{~Pa}$ ) promoted differentiation and intestinal organoid formation, suggestive of a role played by matrix stiffness in regulating cell proliferation versus differentiation in $3 \mathrm{D}$ environments (Gjorevski et al., 2016). Earlier studies also revealed an important function of matrix stiffness in lineage specification of mesenchymal stem cells in 2D (Engler et al., 2006) and 3D environments (Huebsch et al., 2010) and ESCs in 2D environments (Chowdhury et al., 2010). As a prime example, precise temporal control of matrix stiffness can be achieved by synthesizing a composite with specific proportions of degradable and non-degradable synthetic hydrogels, thus providing additional guidance to stem cell renewal and differentiation as shown in intestinal organoid cultures (Gjorevski et al., 2016).

3.2 CHARACTERIZATION OF ECM IN IN VITRO CULTURES AND DURING DEVELOPMENT. ECM composition and architecture is under constant remodeling during normal development (Daley et al., 2008) and ESC differentiation. Data from human embryonic liver development demonstrated dynamic expression pattern of integrins and ECM components (Couvelard et al., 1998). During embryoid body formation from human ESCs, the expression of fibronectin was spatiotemporally correlated with the expression of a definitive endoderm marker GATA4 (Taylor-Weiner et al., 2013). A reverse correlation was found with the expression of a 
pluripotent marker NANOG. Directed differentiation of ESCs to definitive endoderm produced fibrillar fibronectin whereas other lineage differentiation or ESC cultures produced punctate fibronectin. Kanninen et al. have recently discovered that integrin expression was dynamic during hepatic differentiation of human ESCs and iPSCs (Kanninen et al., 2016). The expression of laminin-511/521-specific integrins increased during definitive endoderm induction and hepatic specification. They showed that laminin-511 and laminin-521 promoted hepatic specification from human definitive endoderm cells (Kanninen et al., 2016). Recombinant laminin-511 and laminin-521 would presumably provide an optimal biochemical cue as a designer matrix to assist generation of liver organoids.

To understand the dynamic changes in ECM, temporal expression studies need to be carried out to examine the changes in ECM molecule expression during consecutive developmental stages. Studying the secretome of a cell population that includes growth factors, extracellular matrices, extracellular proteinases, and enzymes may prove to be extremely useful. For example, transcriptomic analyses have been performed to determine the changes in secretome across several early kidney developmental stages (Martinez et al., 2006). More advanced technology involving the use of automated and high-throughput tandem mass spectrometry (MS) can be employed to identify the secretome and the proteome of the ECM of cultured cells under various experimental conditions and of in vivo tissues across developmental stages (Byron et al., 2013; Ngounou Wetie et al., 2013). Steps such as sample or peptide fractionation and liquid chromatography (LC) prior to MS can help reduce sample complexity and ease the identification of ECM components. Such approaches had been successfully used to identify tens to hundreds of ECM components from tissues ranging from eyes to mammary glands to cartilages (Byron et al., 2013). Solid-state NMR spectroscopy and matrix-assisted laser desorption ionization time-of-flight mass spectrometry (MALDI-TOF MS) have been suggested for the compositional analysis of natural ECM and bioengineered tissues (Schiller and Huster, 2012). Low abundant proteins can be detected directly with high-resolution MS or a coupled LC and LC-MS/MS system (i.e. ESI-Q-TOF MS, FT-ICR-MS) (Personal communication with Dr. Andrzej Ciechanowicz). To investigate a more dynamic biological system, as occurs in development, quantification of the relative or absolute amount of particular ECM and secretome components can be achieved by MS using isotope labeling or other label-free strategies. Key ECM and secreted biologically-active protein components identified from secretome assay could be tested for functionality in promoting organoid formation and development via loss-of-function experiments or ectopic administration. Recently, an ECM array platform has been developed to empirically examine the composition of ECM molecules permissive for definitive endoderm differentiation towards the liver and pancreatic lineages (Braga Malta et al., 2016). Coupling array studies with the protein expression data from MS assays will provide valuable information for formulating designer matrices in organoid formation.

3.3 APPLICATIONS OF DESIGNER MATRICES. To incorporate the dynamic changes in ECM composition into organoid differentiation protocols, one may passage dissociated organoid cells at defined time points onto predesigned matrices and scaffolds or may incorporate relevant ECM components into a bio-inert scaffold or hydrogel with degradable matrices, as described previously (Gjorevski et al., 2016). The same study found that a synthetic hydrogel, polyethylene glycol, did not support organoid formation (Gjorevski et al., 2016). Polyethylene glycol cannot interact with cells; it only provides physical support. This finding indicates that additional biochemical signals generated by the biologically-active matrices were critical for organoid formation. Biologically-active matrices can generate signals either by 
directly interacting with cell membrane receptors such as integrins or by binding to growth factors. Many ECM components have integrin-binding domains and/or growth-factor-binding domains, which can be incorporated into designer matrices. It is well-known that the ECM binds and influences the activities of growth factors (Rozario and DeSimone, 2010). More sophisticated design of matrices can be used to create concentration gradients of growth factors, thereby guiding morphogenetic events. Growth factors can also be conjugated on matrices to sustain their releases to cells during prolonged organoid cultures (Lutolf and Hubbell, 2005).

To achieve endogenous matrix architecture, a recent study used multi-photon excited 3D printing technology to produce an ECM scaffold that mimics the developing mouse heart tissues with submicron resolution (Gao et al., 2017). The scaffold was seeded with component cell types of developing heart derived from human ESC and iPSC, such as cardiomyocytes, endothelial cells, and smooth muscle cells. The resultant so-called cardiac muscle patches, although much smaller in size than regular organoids, tested positive for cell engraftment and increased cardiac function in a mouse model for cardiac infarction. In this study, however, only fibronectin was used. Incorporation of multiple relevant ECM molecules mimicking the endogenous composition of ECM in the heart and other organ systems will enhance the applicability of this 3D scaffold printing technology.

Collectively we propose that designer matrices fabricated based on the understanding of the dynamic changes in ECM parameters during in vivo organ and tissue development and robust empirical testing could maximize the self-organizing capacity of cells and provide an optimal environment for human organoid formation.

\section{PROMOTING THE MATURATION OF ORGANOIDS}

In vitro organoid cultures have thus far failed to produce fully-mature cell types. Intestinal, gastric, lung, kidney, and cerebral organoids derived from human ESCs and iPSCs exhibit immature phenotypes, resembling human fetal organs (Camp et al., 2015; Dye et al., 2015; Finkbeiner et al., 2015; Hohwieler et al., 2017; McCracken et al., 2014; Takasato et al., 2015). To promote the maturation of in vitro-derived organoids, maturation factors need to be introduced and culturing conditions must be adjusted at subsequent stages of differentiation to drive the transition of fetal organoids into more adult-like phenotype. Narrowly, "maturation factors" could refer to proteins or chemical factors secreted from cells that promote the maturation of fetal tissues towards more adult-like tissues. In a broader sense, they could refer broadly to factors ranging from cell-cell interacting factors, circulating hormones, microbialderived factors (Avior et al., 2015), electrical signals to other unknown factors that could promote the same process for specific cell types. There is ongoing debate on how maturation of embryonic tissues is achieved. One hypothesis suggests that tissue maturation is driven by the induction of adult stem cells in fetal tissues. An alternative hypothesis suggests that authentic tissue-specific fetal stem cells, distinct from adult stem cells, exist during development and contribute to tissue maturation. In this section, we review studies and propose a number of approaches with which maturation of organoids could potentially be achieved. Furthermore, we review current studies that attempt to promote the in vitro maturation of organoids with variable successes.

4.1 ORGANOID MATURATION UPON TRANSPLANTATION. There are concerns that organoids derived from human ESC and iPSC, even after prolonged cultures, might be unable to mature in vitro to become adult-like tissues. However, that transplantation into animal tissues in many cases induces maturation of human organoids (Cho et al., 2017; Finkbeiner et al., 
2015; Takebe et al., 2013; Watson et al., 2014; Workman et al., 2017) suggests that functional maturation of in vitro organoids could be achieved. For instance, transplantation into the kidney capsule of mice promoted the maturation of both the intestinal and the enteric nervous system of human intestinal organoids (with neural crest-derived enteric neurons) after engraftment for 6 to 10 weeks (Workman et al., 2017). Highly mature intestinal tissues, with villi and crypts containing functional intestinal stem cells, were formed in vivo. Enteric neurons and glia were organized into ganglionic structures in close proximity to the submucosal and myenteric layers of smooth muscle fibers. Nitric oxide synthase expression was detected upon transplantation, another sign of maturation of the enteric nervous system. One possible explanation is that vascularization of organoid structures brings in by the blood stream active components like hormones and serum proteins that could assist a general tissue maturation process. This notion is supported by the enhanced maturation of human intestinal and liver organoids upon ectopic transplantation into adult tissue sites away from their organs of origin, such as to kidney capsule and brain respectively when compared with in vitro cultured organoids (Finkbeiner et al., 2015; Takebe et al., 2013). Another possibility is that this transplantationinduced maturation could be due to the direct contact of immature organoid cell types with an adult environment. For instance, adult stem cell niche factors, present in the in vivo tissues, may play a role during the maturation process (section 4.2).

4.2 ADULT STEM CELL NICHE FACTORS AS POTENTIAL MATURATION FACTORS. Adult stem cells (also called tissue stem cells) reside in a tissue-specific environment, called the stem cell niche. A stem cell niche maintains the self-renewal of adult stem cells and is comprised of ECM, soluble factors, and in some cases niche support cells (Rojas-Rios and Gonzalez-Reyes, 2014). Organoids have been derived from adult stem cellcontaining tissues, such as the intestinal crypts (Sato et al., 2009), the colonic crypts (Sato et al., 2011), the gastric glands (Barker et al., 2010; Bartfeld et al., 2015), the biliary ducts (Huch et al., 2013b), and the pancreatic ducts (Boj et al., 2015; Huch et al., 2013a). To demonstrate the selfrenewal and multipotency of adult stem cells, organoids have also been clonally derived from single proliferative adult stem cells isolated from a number of mouse and human organs and tissues including the small intestines (Sato et al., 2009), the colons (Sato et al., 2011), the gastric pyloric glands (Barker et al., 2010), the gastric corpus tissues (Bartfeld et al., 2015), the pancreatic ducts (Huch et al., 2013a), the biliary ducts (Huch et al., 2013b), the liver (Huch et al., 2015), the lungs (Kumar et al., 2011; McQualter et al., 2010), the prostate gland (Chua et al., 2014; Karthaus et al., 2014), the mammary glands (Jamieson et al., 2016; Shackleton et al., 2006), the salivary glands (Nanduri et al., 2014), the retina (Tropepe et al., 2000), and the fallopian tubes (Kessler et al., 2015). Adult stem cell-derived organoid structures were formed either via the curling up of adult stem cell-containing tissue fragments or via cell division of single stem cells into closed cyst-like structures. Most of the clonally derived adult stem cell organoids were embedded within laminin-rich Matrigel and comprised only of epithelial cells without the presence of stromal and mesenchymal cell types. In rare cases when intestinal tissue fragments that contained stroma were cultured, the derived organoids would consist of polarized epithelial cells surrounded by myofibroblasts and the epithelial compartment developed both crypt-like structures and villus-like protrusions into the lumens (Ootani et al., 2009). Adult stem cell-derived gastric organoids showed higher expression of differentiated markers for glandular cell types such as mucous neck, chief or endocrine cells (Muc6, Pgc, Gif, Chga, Chgb, Sst, and Gast) (Fernandez Vallone et al., 2016). Transcriptomes of organoids derived from adult stem cells clustered with their corresponding adult cells based on gene expression profiling studies. 
While global gene expression profiling by RNA sequencing revealed that human gastric organoids derived from human ESCs/iPSCs resembled human fetal instead of adult stomach tissues (McCracken et al., 2014). There is no single study to our knowledge that has directly compared the transcriptomes of organoids derived from human ESCs/iPSCs and adult stem cells.

Adult stem cell-derived organoids are cultured in conditions that attempt to mimic the paracrine signals and the ECM components provided by their corresponding stem cell niches. Identification of these culturing parameters and conditions may prove beneficial in identifying cues to control the expansion and maturation of organoids derived from human ESCs and iPSCs. The commonly used niche factors in mouse intestinal organoid cultures are EGF, Noggin, and Rspondin 1 (abbreviated as ENR condition). ENR condition was sufficient to maintain mouse intestinal stem cell self-renewal and promoted differentiation to all intestinal epithelial lineages. To further promote self-renewal and suppress differentiation of stem cells, two small molecules, a glycogen synthase kinase $3 \beta$ inhibitor CHIR 99021 and a histone deacetylase inhibitor valproic acid, have been employed (Yin et al., 2014). Under this condition, morphology of organoids became homogenous and formed elongated crypt (budding) structures. Intestinal stem cells (Lgr5-GFP) were also found throughout the organoids. In contrast, manipulation of Wnt and Notch signaling directed differentiation of organoids into specific lineages such as enterocytes, goblet cells or Paneth cells (Yin et al., 2014).

Other types of adult stem cell organoids required not only the ENR condition but also additional factors for self-renewal and growth. Some of these additional factors may suppress differentiation. For example, on top of ENR, mouse colon organoid cultures required exogenous Wnt3A (Sato et al., 2011); human intestinal and colon organoid cultures Wnt3A, gastrin, nicotinamide, a TGF $\beta$ inhibitor A-83-01, and a p38 inhibitor SB202190 (Sato et al., 2011); mouse gastric organoid cultures Wnt3A and FGF10 (Barker et al., 2010); and human gastric organoids Wnt, gastrin, FGF10, and A-83-01 (Bartfeld et al., 2015). To induce or control the rate of differentiation, some of the niche factors were removed or their concentrations adjusted. Mouse colon organoids and human intestinal and colon organoids under growth conditions did not produce differentiated cells. To induce differentiation, Wnt3A, A-83-01, and SB202190 needed to be withdrawn (Sato et al., 2011). Also, mouse gastric organoids under growth condition expressed gastric epithelial markers but lacked markers of pit and enteroendocrine lineages (Barker et al., 2010). Reduction in Wnt3A concentration resulted in the formation of pit cells, mucus neck cells, and enteroendocrine cells. Differentiation of human gastric organoids could be controlled by addition of nicotinamide for gland-type organoids and withdrawal of Wnt for pit-type organoids (Bartfeld et al., 2015).

In the normal adult liver, stem cells have been identified in the pericentral (Wang et al., 2015) and periportal regions (Miyajima et al., 2014). These stem cells can give rise to both hepatocytes and biliary epithelial cells (cholangiocytes). EPCAM is a marker for these liver stem cells (Schmelzer et al., 2007). EPCAM ${ }^{+}$cells from bile ducts of adult human liver produced organoids in the presence of EGF, R-spondin 1, FGF10, nicotinamide, HGF, a TGF $\beta$ inhibitor A83-01, and a cAMP pathway agonist Forskolin (Huch et al., 2015). In vitro hepatocyte differentiation of the organoids required BMP7 treatment followed by the withdrawal of Rspondin 1, FGF10, nicotinamide, and Forskolin and the addition of FGF19, DAPT, and dexamethasone. The resulting cells exhibited hepatocyte morphology, expressed high levels of hepatocyte markers and performed liver functions, such as albumin secretion, CYP3A4 activity, LDL uptake, glycogen storage, bile acid salt secretion, and ammonia detoxification. Upon transplantation, human liver organoid cells also became hepatocyte-like cells and produced 
human albumin, though the level was lower than that produced by transplanted primary human hepatocytes.

Pancreatic ductal organoids have been generated from duct fragments or ductal cells of normal mouse pancreas using ENR, FGF10, nicotinamide, and gastrin; human pancreatic organoids additionally required Wnt3A, A-83-01, and prostaglandin E2 (Boj et al., 2015; Huch et al., 2013a). These organoids exhibited budding structures with an enriched ductal cell population, but they were devoid of acinar and endocrine lineages (Boj et al., 2015). Following orthotopic transplantation into the tail region of the mouse pancreas, both mouse and human organoids developed ductal structures evidenced by the expression of CK19, but the presence of other lineages was not reported (Boj et al., 2015).

Regeneration of ectoderm-derived tissues has enormous value in treatments of degenerative diseases such as age-related macular degeneration and Alzheimer's disease. By colony-forming assay, retinal stem cells were identified from the ciliary margin in the adult mouse eye (Tropepe et al., 2000). These cells were pigmented cells that could clonally proliferate and give rise to spheres in vitro. FGF2 signaling promoted their proliferation and colony forming ability. A single pigmented cell from the ciliary margin generated in 7 days a large sphere consisting of 13,000 pigmented and non-pigmented cells. They proliferated as spheres and acquired the expression of $\mathrm{CHX10}$ and nestin. Under differentiation conditions, the cells in spheres differentiated into MAP2-expressing neuronal cells and GFAP-expressing glial cells. Some undifferentiated nestin-positive cells remained in the center of spheres. When the cells from spheres were cultured in 2D under the same differentiation condition, they became flattened pigmented cells without neural markers.

Collectively, the use of adult stem cells in organoid generation has been mostly from endoderm-derived epithelial tissues (intestine, colon, stomach, liver, pancreas, lung, and prostate), a few ectoderm-derived epithelial tissues (mammary gland, retina, and salivary gland), and mesoderm-derived epithelial tissue (fallopian tubes) (summarized in Table 2). There is no current attempt to bridge our understanding on the culturing conditions for adult stem cellderived and ESC- and iPSC-derived organoid cultures. Owing to the functions of stem cell niches in controlling proliferation and differentiation of adult stem cells, conditions mimicking the paracrine signals and the ECM components provided by their corresponding stem cell niches would be ideal for adult stem cell-derived organoids. However, only the design of intestinal organoid cultures was based on its niche. Other types of organoid cultures were developed by modifying the existing intestinal organoid conditions. Essential niche factors for other organ and tissue systems are not well characterized.

\subsection{EXPLORING DEVELOPMENTAL CUES IDENTIFIED DURING NORMAL} FETAL TO ADULT TRANSITION. Recent studies on a number of human fetal tissues suggest the existence of fetal stem cells, which display distinct features and differentiation potentials from adult stem cells. For instance, stem cell populations have been identified and isolated from a number of human fetal tissues like neuroretina (Zhou et al., 2015), kidney (Da Sacco et al., 2017), heart muscle (Leung et al., 2015), skeletal muscle (Alexander et al., 2016), pancreas (Bonfanti et al., 2015), intestine (Fernandez Vallone et al., 2016), and brain (Kallur et al., 2006; Kim et al., 2006), which are proliferative, self-renewing, and maintain tissue specific gene signatures when cultured in vitro. For instance, fetal enterospheres can be established from proliferative progenitors derived from human fetal intestinal tissues at gestational week 10 and the correspondingly-aged mouse fetal intestinal tissues at embryonic day 16.5 (Fordham et al., 2013). These fetal enterospheres could be passaged for an extended period of time (up to 2 
761

762

763

764

765

766

767

768

769

770

771

772

773

774

775

776

777

778

779

780

781

782

783

784

785

786

787

788

789

790

791

792

793

794

795

796

797

798

799

800

801

802

803

804

805

months for human and 2 years for mouse), were cultured in specific medium conditions distinct from adult organoids (ENR condition with the addition of PGE2 for human and ENR medium alone for mouse), and exhibited a smooth spheroid morphology in contrast to those organoids derived from Lgr5+ adult stem cells, which had budding protrusions on their surfaces. Apart from morphology, there are also distinct gene signatures that define adult stem cells and fetal progenitors. For instance, $L G R 5$ specifically labeled adult stem cells in the intestine and the stomach (Barker et al., 2010; Huch et al., 2013b; Sato et al., 2009) but was expressed at relatively low levels in fetal tissues (Fernandez Vallone et al., 2016). Instead, fetal tissues were characterized by high expression of genes such as TROP2 and TNFRSF19 (Fernandez Vallone et al., 2016). So far, the differences found in organoid morphologies, culturing requirements, and gene expression profiles have been mainly characterized in adult and fetal intestines. Further investigation needs to be performed on other developing and adult organ systems to validate the generality of this phenomenon. These results so far support the notion that immature proliferative progenitors exist in mammalian fetal tissues and are developmentally distinct from adult stem cells in terms of the organoid structures they derive, their gene expression profiles, and their signaling requirements.

Studying the natural fetal to adult transition of embryonic tissues bears enormous implications on how to promote terminal differentiation of ESC- and iPSC-derived tissuespecific cell types, which very often suffer from an insufficient degree of cellular maturation. It is therefore imperative to promote studies in mammalian species to understand the signaling events and gene expression dynamics during the normal developmental transition of fetal tissues towards adulthood. Studies focusing on analyzing the stage-wise morphological and transcriptomic changes of fetal and perinatal tissues are particularly useful in identifying tissuespecific and functionally-relevant gene markers to label and isolate stem cell and progenitor populations from differentiating human ESCs and iPSCs. By performing a three-way comparison between the transcriptomes of human intestinal organoids derived from pluripotent stem cells and human fetal and adult intestinal tissues, Finkbeiner et al. identified OLFM4 as a marker for intestinal tissue maturation, with enhanced specificity compared to the traditional adult stem cell marker LGR5 (Finkbeiner et al., 2015). In another study, microarray datasets of developing mouse heart tissues were collected and their transcriptomes were analyzed to reconstruct a gene regulatory network involved in heart maturation (Uosaki et al., 2015). Pathway analyses were employed to identify key pathways and upstream regulators activated at subsequent embryonic and adult stages. For example, the authors identified that the peroxisome proliferator-activated receptor (PPAR) pathway became increasingly active during subsequent developmental stages in the heart and therefore correlated to cardiac tissue maturation. In a similar study, matched human fetal atrial and ventricular heart tissues at first and second trimester stages corresponding to 7, 15, and 20 weeks of gestation were analyzed using microarrays (van den Berg et al., 2015). Ventricular- and atrial-specific gene signatures were identified. Interestingly, genes encoding histone $\mathrm{H} 1$ variants such as HIST1H3I, HIST1H2BM, and HIST1H2A1, and those for the ECM collagens such as COL1A2, COL2A1, and COL15A1 were downregulated and upregulated respectively in second trimester heart tissues as compared to those from the first trimester, suggestive of a developmental change in gene expression pattern during human heart tissue maturation. In order to translate these transcriptomic studies into useful information for in vitro organoid cultures, gain- and loss-of-function experiments can be carried out in animals to identify key molecules and pathways regulating the maturation of specific tissues. 
4.4 CURRENT ATTEMPTS ON PROMOTING ORGANOID MATURATION. A number of studies have attempted to promote in vitro maturation in human organoids. One approach aims to generate reporter lines that allow isolation of the rare adult stem cell populations from differentiated human ESC and iPSC cultures. Using zinc finger genome editing technology, Forster et al. engineered a GFP reporter insertion into the endogenous locus of the intestinal adult stem cell marker LGR5 (Forster et al., 2014). By flow cytometry-assisted sorting of teratoma tissues derived from this knock-in human iPSC line, the authors were able to isolate $\mathrm{LGR}^{+}$progenitors that could form organoids similar in culturing conditions and differentiation potentials to intestinal organoids derived from LGR $5^{+}$adult stem cells. They additionally found that maintenance of these adult stem cell-like derived organoids required both WNT and Notch signaling. A second approach aims to identify conditions for maturation either empirically or by inference from culturing conditions of adult stem cells. For instance, it was found that maturation medium containing T3 hormone significantly promoted the maturation of in vitro human ESCand iPSC-derived cardiomyocytes, which corresponded to second trimester human heart tissues (van den Berg et al., 2015). The maturation status of those cardiomyocytes not treated with the maturation medium remained at first trimester. One key feature of primate cerebral cortex is the presence of gyrification. Human cerebral organoids generated so far lack cortical folding. A recent study suggests that enhanced AKT signaling caused by PTEN mutation promotes formation of folds in human cerebral organoids ( $\mathrm{Li}$ et al., 2017). It is unknown whether in vitro activation of AKT pathway may promote maturation of cerebral cortical organoids. Many adult stem cell organoid markers are WNT targets, suggesting that adult organoids likely have high WNT signaling and activation of WNT signaling could promote fetal-to-adult transition of fetal organoids. Indeed, it has been shown that inclusion of Wnt3 A ligand in cultures for fetal progenitor derived enterospheres could promote their maturation into adult stem cell-like derived organoids (Fordham et al., 2013). Some other studies have started to exploit whether ECM and bioengineered scaffolds may provide cues for maturation. For instance, salivary gland spheres were expanded in Matrigel and then differentiated into organoids in a mixture of Matrigel and collagen (Nanduri et al., 2014). Another recent study reports improved maturation and engraftment of lung organoids by using a microporous poly(lactide-co-glycolide) scaffold (Dye et al., 2016). These experiments strongly suggest that, to a certain extent, maturation of organoids is achievable in vitro.

\section{BIOMEDICAL APPLICATIONS AND PERSPECTIVES OF NEXT GENERATION HUMAN ORGANOIDS}

A number of excellent reviews have recently been published on the usage of organoids in pharmaceutical and clinical research. Here, we aim to highlight the potential improvements on organoid synthesis that our review discusses and propose studies that will benefit a range of biomedical applications including disease modeling, drug discovery, and tissue transplantation.

\subsection{MIMICKING THE COMPLEX CELLULAR HETEROGENEITY OF} UNDERSTUDIED ORGANS AND TISSUES. So far, most of our discussion has been limited to internal organs and brain tissues. Organoids or 3D cultures for many other tissues, especially those that involved the incorporation of ectoderm-derived cell types, such as inner ears, cranial ganglia, skin, limbs, and eyes, have been less commonly attempted. The major difficulty associated with synthesizing organoids for these tissues is the lack of robust differentiation approaches for the co-induction of specific progenitors in the right proportions from the same or different germ layers. For instance, the mammalian ear, which includes the outer, middle, and 
852

853

854

855

856

857

858

859

860

861

862

863

864

865

866

867

868

869

870

871

872

873

874

875

876

877

878

879

880

881

882

883

884

885

886

887

888

889

890

891

892

893

894

895

896

897

inner ear, is derived from cell types generated from all three germ layers. Defects in any of the cell components could lead to conductive or sensory hearing loss. Another example is the ganglionic structures that develop in the head region, such as the trigeminal and vestibulocochlear ganglia, the latter of which contributes to the inner ear. Disorders like sensory or age-related hearing loss and migraine arise from malfunctions of these ganglia. These ganglia are composed of sensory neurons, which are derived from cranial placodes, and glial cell types, from neural crest. Both cranial placodes and neural crest are ectoderm derived but their induction regimes in ESCs and iPSCs differ dramatically (Dincer et al., 2013; Leung et al., 2013; Leung et al., 2016; Menendez et al., 2011; Mica et al., 2013). Neurovascular networks for internal organs are composed of autonomic neurons, endothelial cells, and vascular smooth muscle cells. The introduction of an intact neurovascular network into organoids for internal organs will allow more precise disease modeling, for instance, for Hirschsprung disease (Workman et al., 2017) or other genetic disorders with a disrupted neurovascular development. A recent study found that proper differentiation of hESC-derived autonomic neurons was dependent on contacts with endothelial cells and vascular smooth muscle cells and that the co-cultures of all three cell types led to the development of an organized neurovascular network (Acevedo et al., 2015). This again demonstrates that physiologically relevant progenitors can self-organize to reform endogenous tissue-like structures in vitro.

5.2 ENHANCING SAFETY, EFFICACY, AND COST-EFFECTIVENESS OF DRUG TESTING. Drug development is an expensive (1.78 billion US dollars for a new molecular entity) and lengthy (average 13.5 years) process (Paul et al., 2010). The biggest challenge facing the pharmaceutical industry is the high attrition rate in drug development. The product failing rates in the United States, Europe, and Japan between 1990 and 2004 had drastically increased, approximately $75 \%$ at preclinical phase, $70 \%$ at phase I, $55 \%$ at both phase II and phase III (Ledford, 2011). A recent study analyzing drug attrition from four major pharmaceutical companies shows that drug toxicity was the primary cause of attrition at preclinical phase and clinical phase I (Waring et al., 2015). The likelihood of final approval counting from the start of clinical phase I was only about $10 \%$ (Hay et al., 2014; Kola and Landis, 2004). The main causes of attrition were lack of efficacy and safety, each contributing to approximately $30 \%$ of failures (Kola and Landis, 2004). During 2007-2010, 66\% of phase III submission failures were attributable to lack of efficacy, particularly in the therapeutic areas of oncology and neurodegeneration, and $21 \%$ of failures were caused by safety issues (Arrowsmith, 2011). Moreover, drug withdrawal from the market due to toxicology has a remarkable impact on the pharmaceutical industry and also on patients. Adverse drug reactions are serious problems and considerably increase morbidity, mortality, and health care costs (Pirmohamed et al., 2004). Drug-induced liver injury was the most common reason for the withdrawal of clinical drugs from the worldwide market during 1953-2013 (18\% of all withdrawals) (Onakpoya et al., 2016). Another study reported the top three reasons for the post-marketing withdrawal in the EU during 2002-2011 were cardiovascular toxicity, hepatotoxicity, and neurotoxicity (McNaughton et al., 2014). To improve R\&D productivity and quality of health care, obtaining human proof-ofconcept data early in drug development and identifying risks at the preclinical phase are crucial.

An ideal in vitro model for preclinical drug testing should mimic human pathophysiology to promote accurate prediction of drug efficacy and toxicity. Next generation human cell-derived organoids generated by the incorporation of the correct cellular heterogeneity, maturation factors, and designer matrices would bear a closer resemblance to the in vivo tissues and organs than conventional 2D cultures and 3D organoids. They would have close to native cellular 
composition and could better predict drug efficacy and toxicity at a tissue or organ level. Also many drug-induced injuries are not caused by direct effects on parenchymal cells but rather caused by immune responses or non-specific systemic effects from non-parenchymal cell types. For instance, some compounds show liver toxicity in vivo but are not toxic to hepatocytes or only at extremely high concentrations, indicating that in vitro testing using only hepatocytes is not adequate to predict hepatotoxicity (Godoy et al., 2013). Non-parenchymal cells in the liver, such as Kupffer cells and hepatic stellate cells, may contribute to inflammation during drug-induced liver injury (Godoy et al., 2013). Liver organoids with Kupffer cells or hepatic stellate cells would predict such hepatotoxicity more accurately than those with primary human hepatocytes, which is the current gold standard for in vitro drug testing. Hepatic stellate cells also contribute to the development of liver fibrosis. Recently human hepatic organoids derived from HepaRG and primary human hepatic stellate cells have been used to evaluate drug-induced liver fibrosis (Leite et al., 2016). Liver organoids derived from human ESCs/iPSCs with normal genotypes would be superior to HepaRG, which is a human hepatocellular carcinoma-derived hepatic progenitor cell line. Organoids derived from human iPSCs of different genetic backgrounds would help develop personalized toxicology, which will pave the way to precision medicine. A study successfully reproduced individual differences in drug metabolism capacity and responsiveness by using a panel of human iPSC-derived hepatocyte-like cells (Takayama et al., 2014). Liver organoids with bile duct-like structures formed by including cholangiocytes would predict drug-induced cholestasis. 3D hepatocyte spheroids derived from human ESCs and iPSCs exhibited increased expression of drug metabolizing enzymes and transporters and increased sensitivity to tested drug compounds, compared to traditional hepatocellular carcinoma-derived cell lines like HepG2 cells (Takayama et al., 2013). Similarly, neurotoxicity has contributed to attrition of drug candidates. A recent study by (Schwartz et al., 2015) has constructed neural organoids using multi-lineage progenitors to mimic the normal composition of cell types during brain development. The system has successfully predicted known toxins in blind screens. Due to the technical difficulty in establishing and maintaining organoid cultures, 2D cell models still dominate the early phases of drug development, such as the lead generation phase. However, due to their enhanced ability to mimic human physiology, organoid cultures are especially valuable in lead optimization and preclinical development.

Increasing demands from patient advocacy groups and the anticipation of changing government policies to introduce new competition among pharmaceutical companies have continuously added tremendous pressure to reduce drug prices and a demand to enhance cost effectiveness in the drug development pipeline. Stem cell differentiation relies heavily on growth factors, which are expensive and short-lived. 2D differentiation allows easy access of growth factors to cultured cells and, in many cases, allowed close to homogeneous induction of progenitor cell types from human ESCs and iPSCs. Coupling an initial 2D differentiation protocol followed by organoid formation would enhance cost-effectiveness. On the other hand, small molecules have been developed to replace growth factors. They are smaller in molecular mass, cheaper and more stable than growth factors. A study testing small molecules for replacing growth factors used in hepatic differentiation of hESCs has shown that the cost could be reduced by $67 \%$ (Tasnim et al., 2015). Small molecules will have better ability to penetrate organoid structures compared to growth factors. Therefore, they are better suited to be employed at later stages of organoid cultures.

5.3 FACILITATING THE SETUP OF VARIOUS BIOENGINEERING APPROACHES. In static cultures, cells in organoids do not experience mechanical signals as 
they do in the body. Dynamic (perfusion) cultures can provide the necessary fluid shear stress and other forces. They also can facilitate the efficient delivery of nutrients and oxygen. Perfusion bioreactors, which allow cultures in much larger scales than microfluidic devices, have been used in tissue engineering for bones (Gaspar et al., 2012) and intestinal tissues (Kim et al., 2007). A recent study reports human liver organoids formed with diameters up to a few millimeters from the self-organization of a conglomerate of genetically engineered adult hepatocytes, liver sinusoidal endothelial cells, and mesenchymal stem cells in a perfusion bioreactor (Ramachandran et al., 2015), suggesting that the principle of self-organization might be applicable to adult cell populations. On the other hand, microfluidic devices have also been used for perfusion cultures. Organ-on-a-chip is a microfluidic cell culture device with hollow microchannels onto which cells are cultured and through which medium is flowed (Bhatia and Ingber, 2014). Organ-on-a-chip devices can be used to culture one or more types of cells simultaneously and to mimic pathophysiological conditions at different levels, such as at the tissue/organ level, where cells from the same tissues and organs are cultured on a chip, or at organism level, where cells from different tissues and organs are used (Huh et al., 2011). Organon-a-chip and human-on-a-chip approaches enable high throughput assays. By using an organon-a-chip device, the organoid-based in vitro model can predict drug response and toxicity at an organismal level. A pioneering human-on-a-chip study has combined multiple cell types in a multi-channel 3D microfluidic cell culture system (Zhang et al., 2009). This system included cell lines representing liver, kidney, lung, and adipose tissues grown in separate channels and cultured with a common medium mimicking blood flow. Similarly, different types of organoids could be cultured in such a multi-channel microfluidic device to build a human-on-a-chip. Organoids could be formed in other culture systems and then transferred to the microfluidic device or could be formed directly in the microfluidic device. Two recent reviews have described the potential of organoid-on-a-chip in biomedical research and applications (Konar et al., 2016; Skardal et al., 2016). Microfabrication can produce topological patterns that are particularly useful for the study of neuronal behavior. Jeong, et al. have created a deep hemicylindrical, microchannel-networked, concave array system for the formation of nerve-like networks (Jeong et al., 2015). Rat embryonic neural progenitor cells self-aggregated into host neurospheroids in concave microwells and satellite neurospheroids in deep hemicylindrical channels. Neurites grew along channels and were bridged by satellite neurospheroids to connect host neurospheroids together. The neural network was shown to transmit signals from one neurospheroid to another. Taken together, other components of our approach, such as the use of empirically tested design matrices to control the microenvironments and the administration of maturation factors specific for different organs and tissues, should also be considered in these systems.

\subsection{MEETING THE DEMANDS FOR HUMAN TISSUES FOR} TRANSPLANTATION. Demand for raw tissue materials for transplantation calls for a supply of in vitro derived, xeno-free, and high-quality human tissues. For instance, for end-stage organ failure, such as liver and heart failure, organ transplantation is the only available treatment. Renal replacement therapy can treat end-stage renal diseases, but kidney transplantation represents the best treatment both for patients' quality of life and cost-effectiveness. Over 4,500 people in Canada (2015 data, https://www.cihi.ca/en/types-of-care/specialized-services/organreplacements/e-statistics-on-organ-transplants-waiting), 120,000 people in the U.S. (2015 data, www.organdonor.gov), 86,000 in the European Unions plus Iceland, Norway, and Turkey (December 2013 data, http://ec.europa.eu/health//sites/health/files/blood tissues_organs/docs/ev_20141126 factsfigure 


\section{0}

991

992

993

994

995

996

997

998

999

1000

1001

1002

1003

1004

1005

1006

1007

1008

1009

1010

1011

1012

1013

1014

1015

1016

1017

1018

1019

1020

1021

1022

1023

1024

1025

1026

1027

1028

1029

1030

1031

1032

1033

1034

1035

s_en.pdf), and 1.5 million in China $(2007$ data, http://www.ghgj.org/Living\%20Organ\%20Transpl.pdf) are on the waiting list for organ transplant. Most of these people need kidney transplantation $(>80 \%)$, followed by liver $(\sim 10 \%)$, heart $(<5 \%)$, lung $(\sim 1 \%)$, and pancreas $(\sim 1 \%)$. In the U.S., from early 1990 s onwards, the gap between the number of people waiting for a transplant and the number of organ donors has continued to widen to over 7 times. Added to the demand, organ donation is still less common in many countries such as China and Japan. Apart from internal organs, there is also increasing demand for human cell and tissue materials to regrow missing bones, muscles, connective tissues, neural plexi, and skin in the face, neck, and extremities resulting from injuries in wars, motor vehicle-related accidents, burns, and natural disasters (Jalali et al., 2014; van Zuijlen et al., 2015).

There are ongoing clinical trials sponsored by the U.S. NIH to conduct transplantation trials using human ESC- and iPSC-derived cardiac progenitors and retinal pigmented epithelial cells (www.clinicaltrials.gov). Clinical data for other more highly demanded tissues for transplantation such as kidney, liver, and pancreas are urgently needed. In animal studies, xenographic transplantation into adult mouse tissues of human liver organoids generated from a composite aggregate of liver progenitors, endothelial cells, and mesenchyme stem cells has been conducted with success (Takebe et al., 2014). To extend its application, such a multi-lineage recombination method using organ-specific progenitors and vascular and mesenchymal stem cell types has been used to successfully reconstruct composite organoids for intestine, lung, kidney, heart, and brain (Takebe et al., 2015). Liver and other organoids derived from these and other studies suffer from a limitation in size, which usually ranged in the millimeter scale, thereby restricting their direct usage in transplantation. To resolve this issue, de-cellularized liver scaffolds from animals and human cadavers or cell-free scaffolds generated from 3D printing technology could be made and seeded with dissociated organ-specific precursors or directly with organoids containing parenchymal, vascular, and other supporting cell types (Collin de l'Hortet et al., 2016). Together with physiologically relevant culturing methods and bioreactor cultures, these scaffolds could physically support the growth of larger organ structures in vitro. Of interest, whole organ de-cellularization has been achieved for liver and a number of other organs including heart, lung, kidney, and pancreas (Scarritt et al., 2015). One of the main challenges in this type of study is to maintain the architecture and composition of the ECM during the decellularization process, such as collagen, laminin, elastin, and fibronectin, and biologically-active molecules, such as growth factors. Synthesizing cell-free scaffolds with xeno-free designer matrices and 3D printing technology is an alternative to using de-cellularized organ scaffolds. A few studies have attempted to re-cellularize lung and kidney scaffolds derived from rhesus monkey's organs with undifferentiated human ESCs (Scarritt et al., 2015). The resultant chimeric organs contain ESCs expressing non-specific markers. Differentiated ESC- and iPSCderived organ progenitors can instead be used for re-cellularization to promote tissue-specific differentiation. For advanced clinical studies, patient-specific iPSCs derived with xeno-free methods should be used to respond to ethical concerns regarding preservation of human embryos and to reduce chances of immune rejection upon transplantation.

\section{CONCLUSION}

In this review, we have highlighted new perspectives and directions that have been initiated in recent organoid studies. The new development will act as a catalyst for the organoid field and provide new directions to other fields, particularly for developmental biology, embryonic stem cell studies, and adult stem cell biology. 
By applying the principle of reverse engineering, we propose a new pipeline for human organoid generation that potentially can greatly enhance the efficiency of generation, the physiological relevance, and the functionality of in vitro derived human organoids. By exploiting the self-organizing property of embryonic progenitors, the dissociation-aggregation approach allows the generation of organoids with enhanced native cellular composition as well as more flexible experimental designs and multi-stage quality controls as progenitor raw materials can be generated in batches, cryopreserved, thawed, and expanded before organoid formation. Designer matrix, whether it is tailor-made, native or a composite of both, helps construct the native microand matrix environment organoid cell types encountered during aggregation, self-organization, and differentiation. Lastly, a rigorous maturation schematic for different organoid systems permits the generation of fully-functional and terminally-differentiated cell types from human organoids that can be used in a wider range of applications and more closely mimic normal human physiology.

To significantly advance human organoid synthesis technology for various applications, there is an urgency to synthesize knowledge and technologies developed in different fields including stem cell biology, developmental biology, matrix biology, systems biology, bioengineering, material science, biostatistics, and bioinformatics. Such endeavors have been made in various fronts and have to be continuously encouraged by government institutions, sponsoring institutions, and other private funding agencies. Continuous education of the public and communications among scientists, the public media, and the public are also paramount in reducing unwarranted skepticism for using stem cell-derived cell types and tissues for basic research and biomedical applications. Various scientific fields, when proposing research, on the other hand, should also avoid over-optimism and fairly evaluate the beneficial effects of stem cell products. 
1061 We would like to express our sincere appreciation to Cayla O. Broton, Raman Nelakanti, Dr. 1062 Andrzej Ciechanowicz, and Dr. Marissa Holmbeck for critical reading of our manuscript and to 1063 Dr. Patrick Tam (Children Medical Research Institute, Australia) for providing valuable 1064 comments and criticism. A.W.L. is grateful to Drs. Martin Garcia-Castro and Andrew Xiao for 1065 their continuous support of his research. A.W.L. is supported by funding from Connecticut 1066 Innovations and the National Institute of Health. The sponsor plays no role in the study design, 1067 collection, analysis, and interpretation of data, neither has it involved in the writing of the report and in decision to submit the article for publication.

The authors declare no conflict of interest. 
1072

1073

1074

1075

1076

1077

1078

1079

1080

1081

1082

1083

1084

1085

1086

1087

1088

1089

1090

1091

1092

1093

1094

1095

1096

1097

1098

1099

1100

1101

1102

1103

1104

1105

1106

1107

1108

1109

1110

1111

1112

1113

1114

1115

1116

\section{Bibliography}

Acevedo, L.M., Lindquist, J.N., Walsh, B.M., Sia, P., Cimadamore, F., Chen, C., Denzel, M., Pernia, C.D., Ranscht, B., Terskikh, A., Snyder, E.Y., Cheresh, D.A., 2015. hESC Differentiation toward an Autonomic Neuronal Cell Fate Depends on Distinct Cues from the Co-Patterning Vasculature. Stem Cell Reports 4(6), 1075-1088.

Alexander, M.S., Rozkalne, A., Colletta, A., Spinazzola, J.M., Johnson, S., Rahimov, F., Meng, H., Lawlor, M.W., Estrella, E., Kunkel, L.M., Gussoni, E., 2016. CD82 Is a Marker for Prospective Isolation of Human Muscle Satellite Cells and Is Linked to Muscular Dystrophies. Cell Stem Cell 19(6), 800-807.

Arora, N., Alsous, J.I., Guggenheim, J.W., Mak, M., Munera, J., Wells, J.M., Kamm, R.D., Asada, H.H., Shvartsman, S.Y., Griffith, L.G., 2017. A process engineering approach to increase organoid yield. Development.

Arrowsmith, J., 2011. Trial watch: phase III and submission failures: 2007-2010. Nat Rev Drug Discov 10(2), 87.

Avior, Y., Levy, G., Zimerman, M., Kitsberg, D., Schwartz, R., Sadeh, R., Moussaieff, A., Cohen, M., Itskovitz-Eldor, J., Nahmias, Y., 2015. Microbial-derived lithocholic acid and vitamin K2 drive the metabolic maturation of pluripotent stem cells-derived and fetal hepatocytes. Hepatology 62(1), 265-278.

Barkauskas, C.E., Cronce, M.J., Rackley, C.R., Bowie, E.J., Keene, D.R., Stripp, B.R., Randell, S.H., Noble, P.W., Hogan, B.L., 2013. Type 2 alveolar cells are stem cells in adult lung. J Clin Invest 123(7), 3025-3036.

Barker, N., Huch, M., Kujala, P., van de Wetering, M., Snippert, H.J., van Es, J.H., Sato, T., Stange, D.E., Begthel, H., van den Born, M., Danenberg, E., van den Brink, S., Korving, J., Abo, A., Peters, P.J., Wright, N., Poulsom, R., Clevers, H., 2010. Lgr5(+ve) stem cells drive selfrenewal in the stomach and build long-lived gastric units in vitro. Cell Stem Cell 6(1), 25-36. Bartfeld, S., Bayram, T., van de Wetering, M., Huch, M., Begthel, H., Kujala, P., Vries, R., Peters, P.J., Clevers, H., 2015. In vitro expansion of human gastric epithelial stem cells and their responses to bacterial infection. Gastroenterology 148(1), 126-136 e126.

Benedetti, V., Brizi, V., Xinaris, C., 2016. Generation of Functional Kidney Organoids In Vivo Starting from a Single-Cell Suspension. Methods Mol Biol.

Bershteyn, M., Nowakowski, T.J., Pollen, A.A., Di Lullo, E., Nene, A., Wynshaw-Boris, A., Kriegstein, A.R., 2017. Human iPSC-Derived Cerebral Organoids Model Cellular Features of Lissencephaly and Reveal Prolonged Mitosis of Outer Radial Glia. Cell Stem Cell.

Bhatia, S.N., Ingber, D.E., 2014. Microfluidic organs-on-chips. Nature biotechnology 32(8), 760-772.

Bianchi, L.M., Person, A.L., Penney, E.B., 2002. Embryonic inner ear cells reaggregate into specific patterns in vitro. J Assoc Res Otolaryngol 3(4), 418-429.

Boj, S.F., Hwang, C.I., Baker, L.A., Chio, II, Engle, D.D., Corbo, V., Jager, M., Ponz-Sarvise, M., Tiriac, H., Spector, M.S., Gracanin, A., Oni, T., Yu, K.H., van Boxtel, R., Huch, M., Rivera, K.D., Wilson, J.P., Feigin, M.E., Ohlund, D., Handly-Santana, A., Ardito-Abraham, C.M., Ludwig, M., Elyada, E., Alagesan, B., Biffi, G., Yordanov, G.N., Delcuze, B., Creighton, B., Wright, K., Park, Y., Morsink, F.H., Molenaar, I.Q., Borel Rinkes, I.H., Cuppen, E., Hao, Y., Jin, Y., Nijman, I.J., Iacobuzio-Donahue, C., Leach, S.D., Pappin, D.J., Hammell, M., Klimstra, D.S., Basturk, O., Hruban, R.H., Offerhaus, G.J., Vries, R.G., Clevers, H., Tuveson, D.A., 2015. Organoid models of human and mouse ductal pancreatic cancer. Cell 160(1-2), 324-338. 
Bonfanti, P., Nobecourt, E., Oshima, M., Albagli-Curiel, O., Laurysens, V., Stange, G., Sojoodi, M., Heremans, Y., Heimberg, H., Scharfmann, R., 2015. Ex Vivo Expansion and Differentiation of Human and Mouse Fetal Pancreatic Progenitors Are Modulated by Epidermal Growth Factor. Stem cells and development 24(15), 1766-1778. Braga Malta, D.F., Reticker-Flynn, N.E., da Silva, C.L., Cabral, J.M., Fleming, H.E., Zaret, K.S., Bhatia, S.N., Underhill, G.H., 2016. Extracellular matrix microarrays to study inductive signaling for endoderm specification. Acta Biomater 34, 30-40.

Burkina, V., Rasmussen, M.K., Pilipenko, N., Zamaratskaia, G., 2017. Comparison of xenobiotic-metabolising human, porcine, rodent, and piscine cytochrome P450. Toxicology 375, 10-27.

Byron, A., Humphries, J.D., Humphries, M.J., 2013. Defining the extracellular matrix using proteomics. Int J Exp Pathol 94(2), 75-92.

Calderon-Gierszal, E.L., Prins, G.S., 2015. Directed Differentiation of Human Embryonic Stem Cells into Prostate Organoids In Vitro and its Perturbation by Low-Dose Bisphenol A Exposure. Plos One 10(7), e0133238.

Camp, J.G., Badsha, F., Florio, M., Kanton, S., Gerber, T., Wilsch-Brauninger, M., Lewitus, E., Sykes, A., Hevers, W., Lancaster, M., Knoblich, J.A., Lachmann, R., Paabo, S., Huttner, W.B., Treutlein, B., 2015. Human cerebral organoids recapitulate gene expression programs of fetal neocortex development. Proc Natl Acad Sci U S A 112(51), 15672-15677.

Cassiman, J.J., Bernfield, M.R., 1974. Morphogenetic properties of human embryonic cells: aggregation of dissociated cells and histogenesis in cultured aggregates. Pediatr Res 8(3), 184-192.

Chen, T., Bai, H., Shao, Y., Arzigian, M., Janzen, V., Attar, E., Xie, Y., Scadden, D.T., Wang, Z.Z., 2007. Stromal cell-derived factor-1/CXCR4 signaling modifies the capillary-like organization of human embryonic stem cell-derived endothelium in vitro. Stem cells 25(2), 392-401.

Cho, G.S., Lee, D.I., Tampakakis, E., Murphy, S., Andersen, P., Uosaki, H., Chelko, S., Chakir, K., Hong, I., Seo, K., Chen, H.V., Chen, X., Basso, C., Houser, S.R., Tomaselli, G.F., O'Rourke, B., Judge, D.P., Kass, D.A., Kwon, C., 2017. Neonatal Transplantation Confers Maturation of PSCDerived Cardiomyocytes Conducive to Modeling Cardiomyopathy. Cell reports 18(2), 571582.

Chowdhury, F., Na, S., Li, D., Poh, Y.C., Tanaka, T.S., Wang, F., Wang, N., 2010. Material properties of the cell dictate stress-induced spreading and differentiation in embryonic stem cells. Nat Mater 9(1), 82-88.

Chua, C.W., Shibata, M., Lei, M., Toivanen, R., Barlow, L.J., Bergren, S.K., Badani, K.K., McKiernan, J.M., Benson, M.C., Hibshoosh, H., Shen, M.M., 2014. Single luminal epithelial progenitors can generate prostate organoids in culture. Nat Cell Biol 16(10), 951-961, 951954.

Clayton, E., Doupe, D.P., Klein, A.M., Winton, D.J., Simons, B.D., Jones, P.H., 2007. A single type of progenitor cell maintains normal epidermis. Nature 446(7132), 185-189.

Cleaver, O., Melton, D.A., 2003. Endothelial signaling during development. Nat Med 9(6), 661-668.

Clevers, H., 2013. The intestinal crypt, a prototype stem cell compartment. Cell 154(2), 274284. 
1161

1162

1163

1164

1165

1166

1167

1168

1169

1170

1171

1172

1173

1174

1175

1176

1177

1178

1179

1180

1181

1182

1183

1184

1185

1186

1187

1188

1189

1190

1191

1192

1193

1194

1195

1196

1197

1198

1199

1200

1201

1202

1203

1204

1205

1206

Cohen, M.A., Wert, K.J., Goldmann, J., Markoulaki, S., Buganim, Y., Fu, D., Jaenisch, R., 2016. Human neural crest cells contribute to coat pigmentation in interspecies chimeras after in utero injection into mouse embryos. Proc Natl Acad Sci U S A 113(6), 1570-1575.

Collin de l'Hortet, A., Takeishi, K., Guzman-Lepe, J., Handa, K., Matsubara, K., Fukumitsu, K., Dorko, K., Presnell, S.C., Yagi, H., Soto-Gutierrez, A., 2016. Liver-Regenerative

Transplantation: Regrow and Reset. Am J Transplant 16(6), 1688-1696.

Couvelard, A., Bringuier, A.F., Dauge, M.C., Nejjari, M., Darai, E., Benifla, J.L., Feldmann, G., Henin, D., Scoazec, J.Y., 1998. Expression of integrins during liver organogenesis in humans. Hepatology 27(3), 839-847.

Crain, S.M., Bornstein, M.B., 1972. Organotypic bioelectric activity in cultured reaggregates of dissociated rodent brain cells. Science 176(4031), 182-184.

Cristobal, A., van den Toorn, H.W., van de Wetering, M., Clevers, H., Heck, A.J., Mohammed, S., 2017. Personalized Proteome Profiles of Healthy and Tumor Human Colon Organoids Reveal Both Individual Diversity and Basic Features of Colorectal Cancer. Cell reports 18(1), 263-274.

Cugola, F.R., Fernandes, I.R., Russo, F.B., Freitas, B.C., Dias, J.L., Guimaraes, K.P., Benazzato, C., Almeida, N., Pignatari, G.C., Romero, S., Polonio, C.M., Cunha, I., Freitas, C.L., Brandao, W.N., Rossato, C., Andrade, D.G., Faria Dde, P., Garcez, A.T., Buchpigel, C.A., Braconi, C.T., Mendes, E., Sall, A.A., Zanotto, P.M., Peron, J.P., Muotri, A.R., Beltrao-Braga, P.C., 2016. The Brazilian Zika virus strain causes birth defects in experimental models. Nature 534(7606), 267-271.

Da Sacco, S., Thornton, M.E., Petrosyan, A., Lavarreda-Pearce, M., Sedrakyan, S., Grubbs, B.H., De Filippo, R.E., Perin, L., 2017. Direct Isolation and Characterization of Human Nephron Progenitors. Stem Cells Transl Med 6(2), 419-433.

Daley, W.P., Peters, S.B., Larsen, M., 2008. Extracellular matrix dynamics in development and regenerative medicine. Journal of cell science 121(Pt 3), 255-264.

Dang, J., Tiwari, S.K., Lichinchi, G., Qin, Y., Patil, V.S., Eroshkin, A.M., Rana, T.M., 2016. Zika Virus Depletes Neural Progenitors in Human Cerebral Organoids through Activation of the Innate Immune Receptor TLR3. Cell Stem Cell 19(2), 258-265.

Dekkers, J.F., Wiegerinck, C.L., de Jonge, H.R., Bronsveld, I., Janssens, H.M., de Winter-de Groot, K.M., Brandsma, A.M., de Jong, N.W., Bijvelds, M.J., Scholte, B.J., Nieuwenhuis, E.E., van den Brink, S., Clevers, H., van der Ent, C.K., Middendorp, S., Beekman, J.M., 2013. A functional CFTR assay using primary cystic fibrosis intestinal organoids. Nat Med 19(7), 939-945.

DeLong, G.R., 1970. Histogenesis of fetal mouse isocortex and hippocampus in reaggregating cell cultures. Dev Biol 22(4), 563-583.

Dianat, N., Dubois-Pot-Schneider, H., Steichen, C., Desterke, C., Leclerc, P., Raveux, A., Combettes, L., Weber, A., Corlu, A., Dubart-Kupperschmitt, A., 2014. Generation of functional cholangiocyte-like cells from human pluripotent stem cells and HepaRG cells. Hepatology 60(2), 700-714.

Dincer, Z., Piao, J., Niu, L., Ganat, Y., Kriks, S., Zimmer, B., Shi, S.H., Tabar, V., Studer, L., 2013. Specification of functional cranial placode derivatives from human pluripotent stem cells. Cell reports 5(5), 1387-1402.

Doupe, D.P., Alcolea, M.P., Roshan, A., Zhang, G., Klein, A.M., Simons, B.D., Jones, P.H., 2012. A single progenitor population switches behavior to maintain and repair esophageal epithelium. Science 337(6098), 1091-1093. 
Dye, B.R., Dedhia, P.H., Miller, A.J., Nagy, M.S., White, E.S., Shea, L.D., Spence, J.R., 2016. A bioengineered niche promotes in vivo engraftment and maturation of pluripotent stem cell derived human lung organoids. Elife 5.

Dye, B.R., Hill, D.R., Ferguson, M.A., Tsai, Y.H., Nagy, M.S., Dyal, R., Wells, J.M., Mayhew, C.N., Nattiv, R., Klein, O.D., White, E.S., Deutsch, G.H., Spence, J.R., 2015. In vitro generation of human pluripotent stem cell derived lung organoids. Elife 4.

Elkasaby, A., Xu, D., Schroter-Kermani, C., Merker, H.J., 1991. Morphology, differentiation and matrix production of liver cells in organoid cultures (high density cultures) of fetal rat livers. Histol Histopathol 6(2), 217-228.

Engler, A.J., Sen, S., Sweeney, H.L., Discher, D.E., 2006. Matrix elasticity directs stem cell lineage specification. Cell 126(4), 677-689.

Fabre, K.M., Livingston, C., Tagle, D.A., 2014. Organs-on-chips (microphysiological systems): tools to expedite efficacy and toxicity testing in human tissue. Exp Biol Med (Maywood) 239(9), 1073-1077.

Fatehullah, A., Tan, S.H., Barker, N., 2016. Organoids as an in vitro model of human development and disease. Nat Cell Biol 18(3), 246-254.

Fernandez Vallone, V., Leprovots, M., Strollo, S., Vasile, G., Lefort, A., Libert, F., Vassart, G., Garcia, M.I., 2016. Trop2 marks transient gastric fetal epithelium and adult regenerating cells after epithelial damage. Development 143(9), 1452-1463.

Finkbeiner, S.R., Hill, D.R., Altheim, C.H., Dedhia, P.H., Taylor, M.J., Tsai, Y.H., Chin, A.M., Mahe, M.M., Watson, C.L., Freeman, J.J., Nattiv, R., Thomson, M., Klein, O.D., Shroyer, N.F., Helmrath, M.A., Teitelbaum, D.H., Dempsey, P.J., Spence, J.R., 2015. Transcriptome-wide Analysis Reveals Hallmarks of Human Intestine Development and Maturation In Vitro and In Vivo. Stem Cell Reports.

Fordham, R.P., Yui, S., Hannan, N.R., Soendergaard, C., Madgwick, A., Schweiger, P.J., Nielsen, O.H., Vallier, L., Pedersen, R.A., Nakamura, T., Watanabe, M., Jensen, K.B., 2013.

Transplantation of expanded fetal intestinal progenitors contributes to colon regeneration after injury. Cell Stem Cell 13(6), 734-744.

Forster, R., Chiba, K., Schaeffer, L., Regalado, S.G., Lai, C.S., Gao, Q., Kiani, S., Farin, H.F., Clevers, H., Cost, G.J., Chan, A., Rebar, E.J., Urnov, F.D., Gregory, P.D., Pachter, L., Jaenisch, R., Hockemeyer, D., 2014. Human intestinal tissue with adult stem cell properties derived from pluripotent stem cells. Stem Cell Reports 2(6), 838-852.

Freedman, B.S., Brooks, C.R., Lam, A.Q., Fu, H., Morizane, R., Agrawal, V., Saad, A.F., Li, M.K., Hughes, M.R., Werff, R.V., Peters, D.T., Lu, J., Baccei, A., Siedlecki, A.M., Valerius, M.T., Musunuru, K., McNagny, K.M., Steinman, T.I., Zhou, J., Lerou, P.H., Bonventre, J.V., 2015. Modelling kidney disease with CRISPR-mutant kidney organoids derived from human pluripotent epiblast spheroids. Nat Commun 6, 8715.

Fuentealba, L.C., Obernier, K., Alvarez-Buylla, A., 2012. Adult neural stem cells bridge their niche. Cell Stem Cell 10(6), 698-708.

Fujii, M., Shimokawa, M., Date, S., Takano, A., Matano, M., Nanki, K., Ohta, Y., Toshimitsu, K., Nakazato, Y., Kawasaki, K., Uraoka, T., Watanabe, T., Kanai, T., Sato, T., 2016. A Colorectal Tumor Organoid Library Demonstrates Progressive Loss of Niche Factor Requirements during Tumorigenesis. Cell Stem Cell 18(6), 827-838.

Fukuda, M., Mizutani, T., Mochizuki, W., Matsumoto, T., Nozaki, K., Sakamaki, Y., Ichinose, S., Okada, Y., Tanaka, T., Watanabe, M., Nakamura, T., 2014. Small intestinal stem cell identity 
1252

1253

1254

1255

1256

1257

1258

1259

1260

1261

1262

1263

1264

1265

1266

1267

1268

1269

1270

1271

1272

1273

1274

1275

1276

1277

1278

1279

1280

1281

1282

1283

1284

1285

1286

1287

1288

1289

1290

1291

1292

1293

1294

1295

1296

1297 is maintained with functional Paneth cells in heterotopically grafted epithelium onto the colon. Genes Dev 28(16), 1752-1757.

Furness, J.B., 2012. The enteric nervous system and neurogastroenterology. Nat Rev Gastroenterol Hepatol 9(5), 286-294.

Gao, L., Kupfer, M., Jung, J., Yang, L., Zhang, P., Sie, Y., Tran, Q., Ajeti, V., Freeman, B., Fast, V., Campagnola, P., Ogle, B., Zhang, J., 2017. Myocardial Tissue Engineering With Cells Derived from Human Induced-Pluripotent Stem Cells and a Native-Like, High-Resolution, 3Dimensionally Printed Scaffold. Circulation research.

Garber, B., Kollar, E.J., Moscona, A.A., 1968. Aggregation in vivo of dissociated cells. 3. Effect of state of differentiation of cells on feather development in hybrid aggregates of embryonic mouse and chick skin cells. J Exp Zool 168(4), 455-472.

Garber, B., Moscona, A.A., 1964. Aggregation in Vivo of Dissociated Cells. I. Reconstruction of Skin in the Chorioallantoic Membrane from Suspensions of Embryonic Chick and Mouse Skin Cells. J Exp Zool 155, 179-201.

Garcez, P.P., Loiola, E.C., Madeiro da Costa, R., Higa, L.M., Trindade, P., Delvecchio, R., Nascimento, J.M., Brindeiro, R., Tanuri, A., Rehen, S.K., 2016. Zika virus impairs growth in human neurospheres and brain organoids. Science 352(6287), 816-818.

Gaspar, D.A., Gomide, V., Monteiro, F.J., 2012. The role of perfusion bioreactors in bone tissue engineering. Biomatter 2(4), 167-175.

Gjorevski, N., Ranga, A., Lutolf, M.P., 2014. Bioengineering approaches to guide stem cellbased organogenesis. Development 141(9), 1794-1804.

Gjorevski, N., Sachs, N., Manfrin, A., Giger, S., Bragina, M.E., Ordonez-Moran, P., Clevers, H., Lutolf, M.P., 2016. Designer matrices for intestinal stem cell and organoid culture. Nature 539(7630), 560-564.

Godoy, P., Hewitt, N.J., Albrecht, U., Andersen, M.E., Ansari, N., Bhattacharya, S., Bode, J.G., Bolleyn, J., Borner, C., Bottger, J., Braeuning, A., Budinsky, R.A., Burkhardt, B., Cameron, N.R., Camussi, G., Cho, C.S., Choi, Y.J., Craig Rowlands, J., Dahmen, U., Damm, G., Dirsch, O., Donato, M.T., Dong, J., Dooley, S., Drasdo, D., Eakins, R., Ferreira, K.S., Fonsato, V., Fraczek, J., Gebhardt, R., Gibson, A., Glanemann, M., Goldring, C.E., Gomez-Lechon, M.J., Groothuis, G.M., Gustavsson, L., Guyot, C., Hallifax, D., Hammad, S., Hayward, A., Haussinger, D., Hellerbrand, C., Hewitt, P., Hoehme, S., Holzhutter, H.G., Houston, J.B., Hrach, J., Ito, K., Jaeschke, H., Keitel, V., Kelm, J.M., Kevin Park, B., Kordes, C., Kullak-Ublick, G.A., LeCluyse, E.L., Lu, P., LuebkeWheeler, J., Lutz, A., Maltman, D.J., Matz-Soja, M., McMullen, P., Merfort, I., Messner, S., Meyer, C., Mwinyi, J., Naisbitt, D.J., Nussler, A.K., Olinga, P., Pampaloni, F., Pi, J., Pluta, L., Przyborski, S.A., Ramachandran, A., Rogiers, V., Rowe, C., Schelcher, C., Schmich, K., Schwarz, M., Singh, B., Stelzer, E.H., Stieger, B., Stober, R., Sugiyama, Y., Tetta, C., Thasler, W.E., Vanhaecke, T., Vinken, M., Weiss, T.S., Widera, A., Woods, C.G., Xu, J.J., Yarborough, K.M., Hengstler, J.G., 2013. Recent advances in 2D and 3D in vitro systems using primary hepatocytes, alternative hepatocyte sources and non-parenchymal liver cells and their use in investigating mechanisms of hepatotoxicity, cell signaling and ADME. Arch Toxicol 87(8), 1315-1530.

Greggio, C., De Franceschi, F., Figueiredo-Larsen, M., Gobaa, S., Ranga, A., Semb, H., Lutolf, M., Grapin-Botton, A., 2013. Artificial three-dimensional niches deconstruct pancreas development in vitro. Development 140(21), 4452-4462.

Greggio, C., De Franceschi, F., Figueiredo-Larsen, M., Grapin-Botton, A., 2014. In vitro pancreas organogenesis from dispersed mouse embryonic progenitors. J Vis Exp(89). 
1298

1299

1300

1301

1302

1303

1304

1305

1306

1307

1308

1309

1310

1311

1312

1313

1314

1315

1316

1317

1318

1319

1320

1321

1322

1323

1324

1325

1326

1327

1328

1329

1330

1331

1332

1333

1334

1335

1336

1337

1338

1339

1340

1341

1342

Hargitt, C.W., 1915. Regenerative potencies of dis of dissociated cells of hydromedus ae. Biol Bull-Us 28(6), 370-384.

Hay, M., Thomas, D.W., Craighead, J.L., Economides, C., Rosenthal, J., 2014. Clinical development success rates for investigational drugs. Nature biotechnology 32(1), 40-51. Hohwieler, M., Illing, A., Hermann, P.C., Mayer, T., Stockmann, M., Perkhofer, L., Eiseler, T., Antony, J.S., Muller, M., Renz, S., Kuo, C.C., Lin, Q., Sendler, M., Breunig, M., Kleiderman, S.M., Lechel, A., Zenker, M., Leichsenring, M., Rosendahl, J., Zenke, M., Sainz, B., Jr., Mayerle, J., Costa, I.G., Seufferlein, T., Kormann, M., Wagner, M., Liebau, S., Kleger, A., 2017. Human pluripotent stem cell-derived acinar/ductal organoids generate human pancreas upon orthotopic transplantation and allow disease modelling. Gut 66(3), 473-486.

Huch, M., Bonfanti, P., Boj, S.F., Sato, T., Loomans, C.J., van de Wetering, M., Sojoodi, M., Li, V.S., Schuijers, J., Gracanin, A., Ringnalda, F., Begthel, H., Hamer, K., Mulder, J., van Es, J.H., de Koning, E., Vries, R.G., Heimberg, H., Clevers, H., 2013a. Unlimited in vitro expansion of adult bi-potent pancreas progenitors through the Lgr5/R-spondin axis. EMBO J 32(20), 2708-2721.

Huch, M., Dorrell, C., Boj, S.F., van Es, J.H., Li, V.S., van de Wetering, M., Sato, T., Hamer, K., Sasaki, N., Finegold, M.J., Haft, A., Vries, R.G., Grompe, M., Clevers, H., 2013b. In vitro expansion of single Lgr5+ liver stem cells induced by Wnt-driven regeneration. Nature 494(7436), 247-250.

Huch, M., Gehart, H., van Boxtel, R., Hamer, K., Blokzijl, F., Verstegen, M.M., Ellis, E., van Wenum, M., Fuchs, S.A., de Ligt, J., van de Wetering, M., Sasaki, N., Boers, S.J., Kemperman, H., de Jonge, J., Ijzermans, J.N., Nieuwenhuis, E.E., Hoekstra, R., Strom, S., Vries, R.R., van der Laan, L.J., Cuppen, E., Clevers, H., 2015. Long-term culture of genome-stable bipotent stem cells from adult human liver. Cell 160(1-2), 299-312.

Huebsch, N., Arany, P.R., Mao, A.S., Shvartsman, D., Ali, O.A., Bencherif, S.A., Rivera-Feliciano, J., Mooney, D.J., 2010. Harnessing traction-mediated manipulation of the cell/matrix interface to control stem-cell fate. Nat Mater 9(6), 518-526.

Huh, D., Hamilton, G.A., Ingber, D.E., 2011. From 3D cell culture to organs-on-chips. Trends Cell Biol 21(12), 745-754.

Humphrey, J.D., Dufresne, E.R., Schwartz, M.A., 2014. Mechanotransduction and extracellular matrix homeostasis. Nat Rev Mol Cell Biol 15(12), 802-812.

Ingber, D.E., 2016. Reverse Engineering Human Pathophysiology with Organs-on-Chips. Cell 164(6), 1105-1109.

Jalali, M., Kirkpatrick, W.N., Cameron, M.G., Pauklin, S., Vallier, L., 2014. Human stem cells for craniomaxillofacial reconstruction. Stem cells and development 23(13), 1437-1451. Jamieson, P.R., Dekkers, J.F., Rios, A.C., Fu, N.Y., Lindeman, G.J., Visvader, J.E., 2016. Derivation of a robust mouse mammary organoid system for studying tissue dynamics. Development. Jeong, G.S., Chang, J.Y., Park, J.S., Lee, S.A., Park, D., Woo, J., An, H., Lee, C.J., Lee, S.H., 2015. Networked neural spheroid by neuro-bundle mimicking nervous system created by topology effect. Mol Brain 8, 17.

Kadoshima, T., Sakaguchi, H., Nakano, T., Soen, M., Ando, S., Eiraku, M., Sasai, Y., 2013. Selforganization of axial polarity, inside-out layer pattern, and species-specific progenitor dynamics in human ES cell-derived neocortex. Proc Natl Acad Sci U S A 110(50), 2028420289. 
1343

1344

1345

1346

1347

1348

1349

1350

1351

1352

1353

1354

1355

1356

1357

1358

1359

1360

1361

1362

1363

1364

1365

1366

1367

1368

1369

1370

1371

1372

1373

1374

1375

1376

1377

1378

1379

1380

1381

1382

1383

1384

1385

1386

1387

1388

Kallur, T., Darsalia, V., Lindvall, O., Kokaia, Z., 2006. Human fetal cortical and striatal neural stem cells generate region-specific neurons in vitro and differentiate extensively to neurons after intrastriatal transplantation in neonatal rats. J Neurosci Res 84(8), 16301644.

Kanninen, L.K., Harjumaki, R., Peltoniemi, P., Bogacheva, M.S., Salmi, T., Porola, P., Niklander, J., Smutny, T., Urtti, A., Yliperttula, M.L., Lou, Y.R., 2016. Laminin-511 and laminin-521based matrices for efficient hepatic specification of human pluripotent stem cells. Biomaterials 103, 86-100.

Karthaus, W.R., Iaquinta, P.J., Drost, J., Gracanin, A., van Boxtel, R., Wongvipat, J., Dowling, C.M., Gao, D., Begthel, H., Sachs, N., Vries, R.G., Cuppen, E., Chen, Y., Sawyers, C.L., Clevers, H.C., 2014. Identification of multipotent luminal progenitor cells in human prostate organoid cultures. Cell 159(1), 163-175.

Kessler, M., Hoffmann, K., Brinkmann, V., Thieck, O., Jackisch, S., Toelle, B., Berger, H., Mollenkopf, H.J., Mangler, M., Sehouli, J., Fotopoulou, C., Meyer, T.F., 2015. The Notch and Wnt pathways regulate stemness and differentiation in human fallopian tube organoids. Nat Commun 6, 8989.

Kim, H.T., Kim, I.S., Lee, I.S., Lee, J.P., Snyder, E.Y., Park, K.I., 2006. Human neurospheres derived from the fetal central nervous system are regionally and temporally specified but are not committed. Experimental neurology 199(1), 222-235.

Kim, S.S., Penkala, R., Abrahimi, P., 2007. A perfusion bioreactor for intestinal tissue engineering. J Surg Res 142(2), 327-331.

Kim, Y., Kim, H., Ko, U.H., Oh, Y., Lim, A., Sohn, J.W., Shin, J.H., Kim, H., Han, Y.M., 2016. Isletlike organoids derived from human pluripotent stem cells efficiently function in the glucose responsiveness in vitro and in vivo. Sci Rep 6, 35145.

Klein, A.M., Nakagawa, T., Ichikawa, R., Yoshida, S., Simons, B.D., 2010. Mouse germ line stem cells undergo rapid and stochastic turnover. Cell Stem Cell 7(2), 214-224.

Kleinstreuer, N.C., Yang, J., Berg, E.L., Knudsen, T.B., Richard, A.M., Martin, M.T., Reif, D.M., Judson, R.S., Polokoff, M., Dix, D.J., Kavlock, R.J., Houck, K.A., 2014. Phenotypic screening of the ToxCast chemical library to classify toxic and therapeutic mechanisms. Nature biotechnology 32(6), 583-591.

Kola, I., Landis, J., 2004. Can the pharmaceutical industry reduce attrition rates? Nat Rev Drug Discov 3(8), 711-715.

Konar, D., Devarasetty, M., Yildiz, D.V., Atala, A., Murphy, S.V., 2016. Lung-On-A-Chip Technologies for Disease Modeling and Drug Development. Biomed Eng Comput Biol 7(Suppl 1), 17-27.

Kretzschmar, K., Clevers, H., 2016. Organoids: Modeling Development and the Stem Cell Niche in a Dish. Dev Cell 38(6), 590-600.

Kumar, P.A., Hu, Y., Yamamoto, Y., Hoe, N.B., Wei, T.S., Mu, D., Sun, Y., Joo, L.S., Dagher, R., Zielonka, E.M., Wang de, Y., Lim, B., Chow, V.T., Crum, C.P., Xian, W., McKeon, F., 2011. Distal airway stem cells yield alveoli in vitro and during lung regeneration following H1N1 influenza infection. Cell 147(3), 525-538.

Lancaster, M.A., Knoblich, J.A., 2014. Generation of cerebral organoids from human pluripotent stem cells. Nature protocols 9(10), 2329-2340.

Lancaster, M.A., Renner, M., Martin, C.A., Wenzel, D., Bicknell, L.S., Hurles, M.E., Homfray, T., Penninger, J.M., Jackson, A.P., Knoblich, J.A., 2013. Cerebral organoids model human brain development and microcephaly. Nature 501(7467), 373-379. 
1389

1390

1391

1392

1393

1394

1395

1396

1397

1398

1399

1400

1401

1402

1403

1404

1405

1406

1407

1408

1409

1410

1411

1412

1413

1414

1415

1416

1417

1418

1419

1420

1421

1422

1423

1424

1425

1426

1427

1428

1429

1430

1431

1432

1433

1434

Layer, P.G., Rothermel, A., Willbold, E., 2001. From stem cells towards neural layers: a lesson from re-aggregated embryonic retinal cells. Neuroreport 12(7), A39-46.

Ledford, H., 2011. Translational research: 4 ways to fix the clinical trial. Nature $477(7366)$, 526-528.

Leite, S.B., Roosens, T., El Taghdouini, A., Mannaerts, I., Smout, A.J., Najimi, M., Sokal, E., Noor, F., Chesne, C., van Grunsven, L.A., 2016. Novel human hepatic organoid model enables testing of drug-induced liver fibrosis in vitro. Biomaterials 78, 1-10.

Leung, A.W., Kent Morest, D., Li, J.Y., 2013. Differential BMP signaling controls formation and differentiation of multipotent preplacodal ectoderm progenitors from human embryonic stem cells. Dev Biol 379(2), 208-220.

Leung, A.W., Murdoch, B., Salem, A.F., Prasad, M.S., Gomez, G.A., Garcia-Castro, M.I., 2016. WNT/beta-catenin signaling mediates human neural crest induction via a pre-neural border intermediate. Development 143(3), 398-410.

Leung, H.W., Moerkamp, A.T., Padmanabhan, J., Ng, S.W., Goumans, M.J., Choo, A., 2015. mAb C19 targets a novel surface marker for the isolation of human cardiac progenitor cells from human heart tissue and differentiated hESCs. Journal of molecular and cellular cardiology 82, 228-237.

Leushacke, M., Ng, A., Galle, J., Loeffler, M., Barker, N., 2013. Lgr5(+) gastric stem cells divide symmetrically to effect epithelial homeostasis in the pylorus. Cell reports 5(2), 349-356. Li, X., Nadauld, L., Ootani, A., Corney, D.C., Pai, R.K., Gevaert, O., Cantrell, M.A., Rack, P.G., Neal, J.T., Chan, C.W., Yeung, T., Gong, X., Yuan, J., Wilhelmy, J., Robine, S., Attardi, L.D., Plevritis, S.K., Hung, K.E., Chen, C.Z., Ji, H.P., Kuo, C.J., 2014. Oncogenic transformation of diverse gastrointestinal tissues in primary organoid culture. Nat Med 20(7), 769-777. Li, Y., Muffat, J., Omer, A., Bosch, I., Lancaster, M.A., Sur, M., Gehrke, L., Knoblich, J.A., Jaenisch, R., 2017. Induction of Expansion and Folding in Human Cerebral Organoids. Cell Stem Cell 20(3), 385-396 e383.

Lippmann, E.S., Al-Ahmad, A., Palecek, S.P., Shusta, E.V., 2013. Modeling the blood-brain barrier using stem cell sources. Fluids Barriers CNS 10(1), 2.

Lippmann, E.S., Azarin, S.M., Kay, J.E., Nessler, R.A., Wilson, H.K., Al-Ahmad, A., Palecek, S.P., Shusta, E.V., 2012. Derivation of blood-brain barrier endothelial cells from human pluripotent stem cells. Nature biotechnology 30(8), 783-791.

Lutolf, M.P., Hubbell, J.A., 2005. Synthetic biomaterials as instructive extracellular microenvironments for morphogenesis in tissue engineering. Nature biotechnology 23(1), 47-55.

Mak, I.W., Evaniew, N., Ghert, M., 2014. Lost in translation: animal models and clinical trials in cancer treatment. Am J Transl Res 6(2), 114-118.

Martin, G.R., 1980. Teratocarcinomas and mammalian embryogenesis. Science 209(4458), 768-776.

Martinez, G., Georgas, K., Challen, G.A., Rumballe, B., Davis, M.J., Taylor, D., Teasdale, R.D., Grimmond, S.M., Little, M.H., 2006. Definition and spatial annotation of the dynamic secretome during early kidney development. Dev Dyn 235(6), 1709-1719.

Matano, M., Date, S., Shimokawa, M., Takano, A., Fujii, M., Ohta, Y., Watanabe, T., Kanai, T., Sato, T., 2015. Modeling colorectal cancer using CRISPR-Cas9-mediated engineering of human intestinal organoids. Nat Med 21(3), 256-262.

McCracken, K.W., Cata, E.M., Crawford, C.M., Sinagoga, K.L., Schumacher, M., Rockich, B.E., Tsai, Y.H., Mayhew, C.N., Spence, J.R., Zavros, Y., Wells, J.M., 2014. Modelling human 
1435

1436

1437

1438

1439

1440

1441

1442

1443

1444

1445

1446

1447

1448

1449

1450

1451

1452

1453

1454

1455

1456

1457

1458

1459

1460

1461

1462

1463

1464

1465

1466

1467

1468

1469

1470

1471

1472

1473

1474

1475

1476

1477

1478

1479 development and disease in pluripotent stem-cell-derived gastric organoids. Nature 516(7531), 400-404.

McDonald, T.F., Sachs, H.G., 1975. Electrical activity in embryonic heart cell aggregates.

Developmental aspects. Pflugers Arch 354(2), 151-164.

McNaughton, R., Huet, G., Shakir, S., 2014. An investigation into drug products withdrawn from the EU market between 2002 and 2011 for safety reasons and the evidence used to support the decision-making. BMJ Open 4(1), e004221.

McQualter, J.L., Yuen, K., Williams, B., Bertoncello, I., 2010. Evidence of an epithelial stem/progenitor cell hierarchy in the adult mouse lung. Proc Natl Acad Sci U S A 107(4), 1414-1419.

Menendez, L., Yatskievych, T.A., Antin, P.B., Dalton, S., 2011. Wnt signaling and a Smad pathway blockade direct the differentiation of human pluripotent stem cells to multipotent neural crest cells. Proc Natl Acad Sci U S A 108(48), 19240-19245.

Mica, Y., Lee, G., Chambers, S.M., Tomishima, M.J., Studer, L., 2013. Modeling neural crest induction, melanocyte specification, and disease-related pigmentation defects in hESCs and patient-specific iPSCs. Cell reports 3(4), 1140-1152.

Miyajima, A., Tanaka, M., Itoh, T., 2014. Stem/progenitor cells in liver development, homeostasis, regeneration, and reprogramming. Cell Stem Cell 14(5), 561-574.

Moscona, A., 1957a. The Development in Vitro of Chimeric Aggregates of Dissociated Embryonic Chick and Mouse Cells. Proc Natl Acad Sci U S A 43(1), 184-194.

Moscona, A., 1957b. Formation of lentoids by dissociated retinal cells of the chick embryo. Science 125(3248), 598-599.

Moscona, A., 1961. Rotation-mediated histogenetic aggregation of dissociated cells. A quantifiable approach to cell interactions in vitro. Exp Cell Res 22, 455-475.

Moscona, A., Moscona, H., 1952. The dissociation and aggregation of cells from organ rudiments of the early chick embryo. J Anat 86(3), 287-301.

Muguruma, K., Nishiyama, A., Kawakami, H., Hashimoto, K., Sasai, Y., 2015. Self-organization of polarized cerebellar tissue in 3D culture of human pluripotent stem cells. Cell reports $10(4), 537-550$.

Nag, A.C., Cheng, M., Healy, C.J., 1980. Coaggregation and formation of a joint myocardial tissue by embryonic mammalian and avian heart cells. J Embryol Exp Morphol 59, 263-279. Nakano, T., Ando, S., Takata, N., Kawada, M., Muguruma, K., Sekiguchi, K., Saito, K.,

Yonemura, S., Eiraku, M., Sasai, Y., 2012. Self-formation of optic cups and storable stratified neural retina from human ESCs. Cell Stem Cell 10(6), 771-785.

Nanduri, L.S., Baanstra, M., Faber, H., Rocchi, C., Zwart, E., de Haan, G., van Os, R., Coppes, R.P., 2014. Purification and ex vivo expansion of fully functional salivary gland stem cells. Stem Cell Reports 3(6), 957-964.

Ngounou Wetie, A.G., Sokolowska, I., Woods, A.G., Wormwood, K.L., Dao, S., Patel, S., Clarkson, B.D., Darie, C.C., 2013. Automated mass spectrometry-based functional assay for the routine analysis of the secretome. J Lab Autom 18(1), 19-29.

Nishimura, W., Kondo, T., Salameh, T., El Khattabi, I., Dodge, R., Bonner-Weir, S., Sharma, A., 2006. A switch from MafB to MafA expression accompanies differentiation to pancreatic beta-cells. Dev Biol 293(2), 526-539.

Odenwald, M.A., Choi, W., Buckley, A., Shashikanth, N., Joseph, N.E., Wang, Y., Warren, M.H., Buschmann, M.M., Pavlyuk, R., Hildebrand, J., Margolis, B., Fanning, A.S., Turner, J.R., 2017. 
1480

1481

1482

1483

1484

1485

1486

1487

1488

1489

1490

1491

1492

1493

1494

1495

1496

1497

1498

1499

1500

1501

1502

1503

1504

1505

1506

1507

1508

1509

1510

1511

1512

1513

1514

1515

1516

1517

1518

1519

1520

1521

1522

1523

1524

ZO-1 interactions with F-actin and occludin direct epithelial polarization and single lumen specification in 3D culture. Journal of cell science 130(1), 243-259.

Onakpoya, I.J., Heneghan, C.J., Aronson, J.K., 2016. Post-marketing withdrawal of 462 medicinal products because of adverse drug reactions: a systematic review of the world literature. BMC Med 14, 10.

Ootani, A., Li, X., Sangiorgi, E., Ho, Q.T., Ueno, H., Toda, S., Sugihara, H., Fujimoto, K., Weissman, I.L., Capecchi, M.R., Kuo, C.J., 2009. Sustained in vitro intestinal epithelial culture within a Wnt-dependent stem cell niche. Nat Med 15(6), 701-706.

Orlova, V.V., van den Hil, F.E., Petrus-Reurer, S., Drabsch, Y., Ten Dijke, P., Mummery, C.L., 2014. Generation, expansion and functional analysis of endothelial cells and pericytes derived from human pluripotent stem cells. Nat Protoc 9(6), 1514-1531.

Orr, M.F., 1968. Histogenesis of sensory epithelium in reaggregates of dissociated embryonic chick otocysts. Dev Biol 17(1), 39-54.

Paul, S.M., Mytelka, D.S., Dunwiddie, C.T., Persinger, C.C., Munos, B.H., Lindborg, S.R., Schacht, A.L., 2010. How to improve R\&D productivity: the pharmaceutical industry's grand challenge. Nat Rev Drug Discov 9(3), 203-214.

Pirmohamed, M., James, S., Meakin, S., Green, C., Scott, A.K., Walley, T.J., Farrar, K., Park, B.K., Breckenridge, A.M., 2004. Adverse drug reactions as cause of admission to hospital: prospective analysis of 18820 patients. BMJ 329(7456), 15-19.

Qian, X., Nguyen, H.N., Song, M.M., Hadiono, C., Ogden, S.C., Hammack, C., Yao, B., Hamersky, G.R., Jacob, F., Zhong, C., Yoon, K.J., Jeang, W., Lin, L., Li, Y., Thakor, J., Berg, D.A., Zhang, C., Kang, E., Chickering, M., Nauen, D., Ho, C.Y., Wen, Z., Christian, K.M., Shi, P.Y., Maher, B.J., Wu, H., Jin, P., Tang, H., Song, H., Ming, G.L., 2016. Brain-Region-Specific Organoids Using Minibioreactors for Modeling ZIKV Exposure. Cell 165(5), 1238-1254.

Ramachandran, S.D., Schirmer, K., Munst, B., Heinz, S., Ghafoory, S., Wolfl, S., Simon-Keller, K., Marx, A., Oie, C.I., Ebert, M.P., Walles, H., Braspenning, J., Breitkopf-Heinlein, K., 2015. In Vitro Generation of Functional Liver Organoid-Like Structures Using Adult Human Cells. Plos One 10(10), e0139345.

Ridgeway, R.D., Hamilton, J.W., MacGregor, R.R., 1986. Characteristics of bovine parathyroid cell organoids in culture. In Vitro Cell Dev Biol 22(2), 91-99.

Rojas-Rios, P., Gonzalez-Reyes, A., 2014. Concise review: The plasticity of stem cell niches: a general property behind tissue homeostasis and repair. Stem cells 32(4), 852-859.

Rozario, T., DeSimone, D.W., 2010. The extracellular matrix in development and morphogenesis: a dynamic view. Dev Biol 341(1), 126-140.

Sato, T., Stange, D.E., Ferrante, M., Vries, R.G., Van Es, J.H., Van den Brink, S., Van Houdt, W.J., Pronk, A., Van Gorp, J., Siersema, P.D., Clevers, H., 2011. Long-term expansion of epithelial organoids from human colon, adenoma, adenocarcinoma, and Barrett's epithelium. Gastroenterology 141(5), 1762-1772.

Sato, T., Vries, R.G., Snippert, H.J., van de Wetering, M., Barker, N., Stange, D.E., van Es, J.H., Abo, A., Kujala, P., Peters, P.J., Clevers, H., 2009. Single Lgr5 stem cells build crypt-villus structures in vitro without a mesenchymal niche. Nature 459(7244), 262-265.

Scarritt, M.E., Pashos, N.C., Bunnell, B.A., 2015. A review of cellularization strategies for tissue engineering of whole organs. Front Bioeng Biotechnol 3, 43.

Schiller, J., Huster, D., 2012. New methods to study the composition and structure of the extracellular matrix in natural and bioengineered tissues. Biomatter 2(3), 115-131. 
Schmelzer, E., Zhang, L., Bruce, A., Wauthier, E., Ludlow, J., Yao, H.L., Moss, N., Melhem, A., McClelland, R., Turner, W., Kulik, M., Sherwood, S., Tallheden, T., Cheng, N., Furth, M.E., Reid, L.M., 2007. Human hepatic stem cells from fetal and postnatal donors. J Exp Med 204(8), 1973-1987.

Schroter-Kermani, C., Hinz, N., Risse, P., Zimmermann, B., Merker, H.J., 1991. The extracellular matrix in cartilage organoid culture: biochemical, immunomorphological and electron microscopic studies. Matrix 11(6), 428-441.

Schwartz, M.P., Hou, Z., Propson, N.E., Zhang, J., Engstrom, C.J., Santos Costa, V., Jiang, P., Nguyen, B.K., Bolin, J.M., Daly, W., Wang, Y., Stewart, R., Page, C.D., Murphy, W.L., Thomson, J.A., 2015. Human pluripotent stem cell-derived neural constructs for predicting neural toxicity. Proc Natl Acad Sci U S A 112(40), 12516-12521.

Seeds, N.W., 1971. Biochemical differentiation in reaggregating brain cell culture. Proc Natl Acad Sci U S A 68(8), 1858-1861.

Seeds, N.W., Vatter, A.E., 1971. Synaptogenesis in reaggregating brain cell culture. Proc Natl Acad Sci U S A 68(12), 3219-3222.

Seok, J., Warren, H.S., Cuenca, A.G., Mindrinos, M.N., Baker, H.V., Xu, W., Richards, D.R., McDonald-Smith, G.P., Gao, H., Hennessy, L., Finnerty, C.C., Lopez, C.M., Honari, S., Moore, E.E., Minei, J.P., Cuschieri, J., Bankey, P.E., Johnson, J.L., Sperry, J., Nathens, A.B., Billiar, T.R., West, M.A., Jeschke, M.G., Klein, M.B., Gamelli, R.L., Gibran, N.S., Brownstein, B.H., MillerGraziano, C., Calvano, S.E., Mason, P.H., Cobb, J.P., Rahme, L.G., Lowry, S.F., Maier, R.V., Moldawer, L.L., Herndon, D.N., Davis, R.W., Xiao, W., Tompkins, R.G., Inflammation, Host Response to Injury, L.S.C.R.P., 2013. Genomic responses in mouse models poorly mimic human inflammatory diseases. Proc Natl Acad Sci U S A 110(9), 3507-3512.

Shackleton, M., Vaillant, F., Simpson, K.J., Stingl, J., Smyth, G.K., Asselin-Labat, M.L., Wu, L., Lindeman, G.J., Visvader, J.E., 2006. Generation of a functional mammary gland from a single stem cell. Nature 439(7072), 84-88.

Shields, J.A., Shields, C.L., Eagle, R.C., Jr., Arevalo, F., De Potter, P., 1996. Ophthalmic features of the organoid nevus syndrome. Trans Am Ophthalmol Soc 94, 65-86; discussion 86-67. Shinozawa, T., Yoshikawa, H.Y., Takebe, T., 2016. Reverse engineering liver buds through self-driven condensation and organization towards medical application. Dev Biol 420(2), 221-229.

Si-Tayeb, K., Lemaigre, F.P., Duncan, S.A., 2010. Organogenesis and development of the liver. Dev Cell 18(2), 175-189.

Skardal, A., Shupe, T., Atala, A., 2016. Organoid-on-a-chip and body-on-a-chip systems for drug screening and disease modeling. Drug Discov Today 21(9), 1399-1411.

Smith, E., Cochrane, W.J., 1946. Cystic organoid teratoma; report of a case. Can Med Assoc J 55(2), 151.

Steinberg, M.S., Gilbert, S.F., 2004. Townes and Holtfreter (1955): directed movements and selective adhesion of embryonic amphibian cells. J Exp Zool A Comp Exp Biol 301(9), 701706.

Suga, H., Kadoshima, T., Minaguchi, M., Ohgushi, M., Soen, M., Nakano, T., Takata, N., Wataya, T., Muguruma, K., Miyoshi, H., Yonemura, S., Oiso, Y., Sasai, Y., 2011. Self-formation of functional adenohypophysis in three-dimensional culture. Nature 480(7375), 57-62. Takahashi, K., Tanabe, K., Ohnuki, M., Narita, M., Ichisaka, T., Tomoda, K., Yamanaka, S., 2007. Induction of pluripotent stem cells from adult human fibroblasts by defined factors. Cell 131(5), 861-872. 
1571

1572

1573

1574

1575

1576

1577

1578

1579

1580

1581

1582

1583

1584

1585

1586

1587

1588

1589

1590

1591

1592

1593

1594

1595

1596

1597

1598

1599

1600

1601

1602

1603

1604

1605

1606

1607

1608

1609

1610

1611

1612

1613

1614

1615
Takahashi, K., Yamanaka, S., 2006. Induction of pluripotent stem cells from mouse embryonic and adult fibroblast cultures by defined factors. Cell 126(4), 663-676. Takasato, M., Er, P.X., Becroft, M., Vanslambrouck, J.M., Stanley, E.G., Elefanty, A.G., Little, M.H., 2014. Directing human embryonic stem cell differentiation towards a renal lineage generates a self-organizing kidney. Nat Cell Biol 16(1), 118-126.

Takasato, M., Er, P.X., Chiu, H.S., Little, M.H., 2016. Generation of kidney organoids from human pluripotent stem cells. Nat Protoc 11(9), 1681-1692.

Takasato, M., Er, P.X., Chiu, H.S., Maier, B., Baillie, G.J., Ferguson, C., Parton, R.G., Wolvetang, E.J., Roost, M.S., Chuva de Sousa Lopes, S.M., Little, M.H., 2015. Kidney organoids from human iPS cells contain multiple lineages and model human nephrogenesis. Nature 526(7574), 564-568.

Takayama, K., Kawabata, K., Nagamoto, Y., Kishimoto, K., Tashiro, K., Sakurai, F., Tachibana, M., Kanda, K., Hayakawa, T., Furue, M.K., Mizuguchi, H., 2013. 3D spheroid culture of hESC/hiPSC-derived hepatocyte-like cells for drug toxicity testing. Biomaterials 34(7), 1781-1789.

Takayama, K., Morisaki, Y., Kuno, S., Nagamoto, Y., Harada, K., Furukawa, N., Ohtaka, M., Nishimura, K., Imagawa, K., Sakurai, F., Tachibana, M., Sumazaki, R., Noguchi, E., Nakanishi, M., Hirata, K., Kawabata, K., Mizuguchi, H., 2014. Prediction of interindividual differences in hepatic functions and drug sensitivity by using human iPS-derived hepatocytes. Proc Natl Acad Sci U S A 111(47), 16772-16777.

Takebe, T., Enomura, M., Yoshizawa, E., Kimura, M., Koike, H., Ueno, Y., Matsuzaki, T., Yamazaki, T., Toyohara, T., Osafune, K., Nakauchi, H., Yoshikawa, H.Y., Taniguchi, H., 2015. Vascularized and Complex Organ Buds from Diverse Tissues via Mesenchymal Cell-Driven Condensation. Cell Stem Cell 16(5), 556-565.

Takebe, T., Sekine, K., Enomura, M., Koike, H., Kimura, M., Ogaeri, T., Zhang, R.R., Ueno, Y., Zheng, Y.W., Koike, N., Aoyama, S., Adachi, Y., Taniguchi, H., 2013. Vascularized and functional human liver from an iPSC-derived organ bud transplant. Nature 499(7459), 481484.

Takebe, T., Zhang, R.R., Koike, H., Kimura, M., Yoshizawa, E., Enomura, M., Koike, N., Sekine, K., Taniguchi, H., 2014. Generation of a vascularized and functional human liver from an iPSC-derived organ bud transplant. Nat Protoc 9(2), 396-409.

Takeichi, M., 2011. Self-organization of animal tissues: cadherin-mediated processes. Dev Cell 21(1), 24-26.

Taniguchi, K., Shao, Y., Townshend, R.F., Tsai, Y.H., DeLong, C.J., Lopez, S.A., Gayen, S., Freddo, A.M., Chue, D.J., Thomas, D.J., Spence, J.R., Margolis, B., Kalantry, S., Fu, J., O'Shea, K.S., Gumucio, D.L., 2015. Lumen Formation Is an Intrinsic Property of Isolated Human Pluripotent Stem Cells. Stem Cell Reports 5(6), 954-962.

Tasnim, F., Phan, D., Toh, Y.C., Yu, H., 2015. Cost-effective differentiation of hepatocyte-like cells from human pluripotent stem cells using small molecules. Biomaterials 70, 115-125. Taylor-Weiner, H., Schwarzbauer, J.E., Engler, A.J., 2013. Defined extracellular matrix components are necessary for definitive endoderm induction. Stem cells 31(10), 20842094.

Thomson, J.A., Itskovitz-Eldor, J., Shapiro, S.S., Waknitz, M.A., Swiergiel, J.J., Marshall, V.S., Jones, J.M., 1998. Embryonic stem cell lines derived from human blastocysts. Science 282(5391), 1145-1147. 
1616

1617

1618

1619

1620

1621

1622

1623

1624

1625

1626

1627

1628

1629

1630

1631

1632

1633

1634

1635

1636

1637

1638

1639

1640

1641

1642

1643

1644

1645

1646

1647

1648

1649

1650

1651

1652

1653

1654

1655

1656

1657

1658

1659

1660

Thomson, J.A., Kalishman, J., Golos, T.G., Durning, M., Harris, C.P., Becker, R.A., Hearn, J.P., 1995. Isolation of a primate embryonic stem cell line. Proc Natl Acad Sci U S A 92(17), 7844-7848.

Townes, P.L., Holtfreter, J., 1955. Directed Movements and Selective Adhesion of Embryonic Amphibian Cells. J Exp Zool 128(1), 53-120.

Tropepe, V., Coles, B.L., Chiasson, B.J., Horsford, D.J., Elia, A.J., McInnes, R.R., van der Kooy, D., 2000. Retinal stem cells in the adult mammalian eye. Science 287(5460), 2032-2036.

Uosaki, H., Cahan, P., Lee, D.I., Wang, S., Miyamoto, M., Fernandez, L., Kass, D.A., Kwon, C., 2015. Transcriptional Landscape of Cardiomyocyte Maturation. Cell reports 13(8), 17051716.

van de Wetering, M., Francies, H.E., Francis, J.M., Bounova, G., Iorio, F., Pronk, A., van Houdt, W., van Gorp, J., Taylor-Weiner, A., Kester, L., McLaren-Douglas, A., Blokker, J., Jaksani, S., Bartfeld, S., Volckman, R., van Sluis, P., Li, V.S., Seepo, S., Sekhar Pedamallu, C., Cibulskis, K., Carter, S.L., McKenna, A., Lawrence, M.S., Lichtenstein, L., Stewart, C., Koster, J., Versteeg, R., van Oudenaarden, A., Saez-Rodriguez, J., Vries, R.G., Getz, G., Wessels, L., Stratton, M.R., McDermott, U., Meyerson, M., Garnett, M.J., Clevers, H., 2015. Prospective derivation of a living organoid biobank of colorectal cancer patients. Cell 161(4), 933-945.

van den Berg, C.W., Okawa, S., Chuva de Sousa Lopes, S.M., van Iperen, L., Passier, R., Braam, S.R., Tertoolen, L.G., del Sol, A., Davis, R.P., Mummery, C.L., 2015. Transcriptome of human foetal heart compared with cardiomyocytes from pluripotent stem cells. Development 142(18), 3231-3238.

van Zuijlen, P., Gardien, K., Jaspers, M., Bos, E.J., Baas, D.C., van Trier, A., Middelkoop, E., 2015. Tissue engineering in burn scar reconstruction. Burns Trauma 3, 18.

Verissimo, C.S., Overmeer, R.M., Ponsioen, B., Drost, J., Mertens, S., Verlaan-Klink, I., Gerwen, B.V., van der Ven, M., Wetering, M.V., Egan, D.A., Bernards, R., Clevers, H., Bos, J.L., Snippert, H.J., 2016. Targeting mutant RAS in patient-derived colorectal cancer organoids by combinatorial drug screening. Elife 5.

Waddell, W.R., 1949. Organoid differentiation of the fetal lung; a histologic study of the differentiation of mammalian fetal lung in utero and in transplants. Arch Pathol (Chic) 47(3), 227-247.

Wang, B., Zhao, L., Fish, M., Logan, C.Y., Nusse, R., 2015. Self-renewing diploid Axin2(+) cells fuel homeostatic renewal of the liver. Nature 524(7564), 180-185.

Waring, M.J., Arrowsmith, J., Leach, A.R., Leeson, P.D., Mandrell, S., Owen, R.M., Pairaudeau, G., Pennie, W.D., Pickett, S.D., Wang, J., Wallace, O., Weir, A., 2015. An analysis of the attrition of drug candidates from four major pharmaceutical companies. Nat Rev Drug Discov 14(7), 475-486.

Watson, C.L., Mahe, M.M., Munera, J., Howell, J.C., Sundaram, N., Poling, H.M., Schweitzer, J.I., Vallance, J.E., Mayhew, C.N., Sun, Y., Grabowski, G., Finkbeiner, S.R., Spence, J.R., Shroyer, N.F., Wells, J.M., Helmrath, M.A., 2014. An in vivo model of human small intestine using pluripotent stem cells. Nat Med 20(11), 1310-1314.

Weeber, F., van de Wetering, M., Hoogstraat, M., Dijkstra, K.K., Krijgsman, O., Kuilman, T., Gadellaa-van Hooijdonk, C.G., van der Velden, D.L., Peeper, D.S., Cuppen, E.P., Vries, R.G., Clevers, H., Voest, E.E., 2015. Preserved genetic diversity in organoids cultured from biopsies of human colorectal cancer metastases. Proc Natl Acad Sci U S A 112(43), 1330813311. 
1661

1662

1663

1664

1665

1666

1667

1668

1669

1670

1671

1672

1673

1674

1675

1676

1677

1678

1679

1680

1681

1682

1683

1684

1685

1686

1687

1688

1689

1690

1691

1692

1693

1694

1695

1696

1697

1698

1699

1700

1701
Wei, C., Larsen, M., Hoffman, M.P., Yamada, K.M., 2007. Self-organization and branching morphogenesis of primary salivary epithelial cells. Tissue Eng 13(4), 721-735.

Weiss, P., Taylor, A.C., 1960. Reconstitution of Complete Organs from Single-Cell

Suspensions of Chick Embryos in Advanced Stages of Differentiation. Proc Natl Acad Sci U S A 46(9), 1177-1185.

Wernig, M., Meissner, A., Foreman, R., Brambrink, T., Ku, M., Hochedlinger, K., Bernstein, B.E., Jaenisch, R., 2007. In vitro reprogramming of fibroblasts into a pluripotent ES-cell-like state. Nature 448(7151), 318-324.

Wilson, A., Trumpp, A., 2006. Bone-marrow haematopoietic-stem-cell niches. Nat Rev Immunol 6(2), 93-106.

Wilson, H.V., 1907. On some phenomena of coalescence and regeneration in sponges. J Exp Zool 5(1-3), 245-258.

Workman, M.J., Mahe, M.M., Trisno, S., Poling, H.M., Watson, C.L., Sundaram, N., Chang, C.F., Schiesser, J., Aubert, P., Stanley, E.G., Elefanty, A.G., Miyaoka, Y., Mandegar, M.A., Conklin, B.R., Neunlist, M., Brugmann, S.A., Helmrath, M.A., Wells, J.M., 2017. Engineered human pluripotent-stem-cell-derived intestinal tissues with a functional enteric nervous system. Nat Med 23(1), 49-59.

Xinaris, C., Benedetti, V., Rizzo, P., Abbate, M., Corna, D., Azzollini, N., Conti, S., Unbekandt, M., Davies, J.A., Morigi, M., Benigni, A., Remuzzi, G., 2012. In vivo maturation of functional renal organoids formed from embryonic cell suspensions. J Am Soc Nephrol 23(11), 1857-1868.

Yin, X., Farin, H.F., van Es, J.H., Clevers, H., Langer, R., Karp, J.M., 2014. Niche-independent high-purity cultures of Lgr5+ intestinal stem cells and their progeny. Nat Methods 11(1), 106-112.

Yoshida, Y., Hilborn, V., Freeman, A.E., 1980. Fine structural identification of organoid mouse lung cells cultured on a pigskin substrate. In Vitro 16(11), 994-1006.

Yu, J., Vodyanik, M.A., Smuga-Otto, K., Antosiewicz-Bourget, J., Frane, J.L., Tian, S., Nie, J., Jonsdottir, G.A., Ruotti, V., Stewart, R., Slukvin, II, Thomson, J.A., 2007. Induced pluripotent stem cell lines derived from human somatic cells. Science 318(5858), 1917-1920.

Yui, S., Nakamura, T., Sato, T., Nemoto, Y., Mizutani, T., Zheng, X., Ichinose, S., Nagaishi, T., Okamoto, R., Tsuchiya, K., Clevers, H., Watanabe, M., 2012. Functional engraftment of colon epithelium expanded in vitro from a single adult Lgr5(+) stem cell. Nat Med 18(4), 618-623. Zhang, C., Zhao, Z., Abdul Rahim, N.A., van Noort, D., Yu, H., 2009. Towards a human-on-chip: culturing multiple cell types on a chip with compartmentalized microenvironments. Lab Chip 9(22), 3185-3192.

Zhao, R., Duncan, S.A., 2005. Embryonic development of the liver. Hepatology 41(5), 956967.

Zhou, P.Y., Peng, G.H., Xu, H., Yin, Z.Q., 2015. c-Kit(+) cells isolated from human fetal retinas represent a new population of retinal progenitor cells. Journal of cell science 128(11), 2169-2178. 
1702

1703

1704

1705

1706

1707

\section{Figure Captions}

Figure 1. A novel pipeline for developing future protocols to generate organoids.

Figure 2. Increased control on the timing of progenitor incorporation into organoid structures.

Figure 3. Dissection of the self-organization process. 
1708 Table 1 - Summary of pioneered animal studies for organ progenitor aggregation

\begin{tabular}{|c|c|c|c|c|c|}
\hline Germ layer & Tissues & Species & $\begin{array}{l}\text { Embryonic } \\
\text { stage }\end{array}$ & $\begin{array}{l}\text { Length of } \\
\text { culture } \\
\text { (days) }\end{array}$ & Reference \\
\hline \multirow[t]{5}{*}{ Ectoderm } & Inner ear & Gallus gallus & & & (Orr, 1968) \\
\hline & Inner ear & Mus musculus & E13-E14 & 6 & (Bianchi et al., 2002) \\
\hline & $\begin{array}{l}\text { Cerebral cortex, } \\
\text { brainstem spinal } \\
\text { cord }\end{array}$ & Mus musculus & & & (Crain and Bornstein, 1972) \\
\hline & Retina & Gallus gallus & & & (Layer et al., 2001) \\
\hline & $\begin{array}{l}\text { Submandibular } \\
\text { gland }\end{array}$ & Mus musculus & E13-E17 & 4 & (Wei et al., 2007) \\
\hline \multirow[t]{3}{*}{ Mesoderm } & Kidney & Mus musculus & $\mathrm{E} 11.5$ & 21 & (Benedetti et al., 2016; Xinaris et al., 2012) \\
\hline & Heart & Gallus gallus & $2.5,4$ or $7 d$ & & (McDonald and Sachs, 1975) \\
\hline & & Gallus gallus, Rat & $50 h, 12 d$ & & (Nag et al., 1980) \\
\hline Endoderm & Pancreas & Mus musculus & $\mathrm{E} 10.5$ & 14 & (Greggio et al., 2013; Greggio et al., 2014) \\
\hline
\end{tabular}

1709 
1710 Table 2. Adult stem cell-derived organoids

\begin{tabular}{|c|c|c|c|c|c|c|}
\hline $\begin{array}{l}\text { Germ } \\
\text { layer }\end{array}$ & Tissue & Species & $\begin{array}{l}\text { Niche factors for } \\
\text { expansion }\end{array}$ & Matrix & $\begin{array}{l}\text { Conditions for in } \\
\text { vitro } \\
\text { differentiation }\end{array}$ & Reference \\
\hline Endoderm & Intestine & Mouse & $\begin{array}{l}\text { EGF, Noggin, R-spondin 1, } \\
\text { Y-27632 (for single cell } \\
\text { culture) }\end{array}$ & Matrigel & $\begin{array}{l}\text { Same as } \\
\text { expansion } \\
\text { condition }\end{array}$ & (Sato et al., 2009) \\
\hline Endoderm & Intestine & Human & $\begin{array}{l}\text { EGF, Noggin, R-spondin 1, } \\
\text { Wnt3A, gastrin, } \\
\text { nicotinamide, A-83-01, } \\
\text { SB202190 }\end{array}$ & Matrigel & $\begin{array}{l}\text { Withdrawal of } \\
\text { Wnt3A, } \\
\text { nicotinamide and } \\
\text { SB202190 }\end{array}$ & (Sato et al., 2011) \\
\hline Endoderm & Colon & Mouse & $\begin{array}{l}\text { EGF, Noggin, R-spondin 1, } \\
\text { Wnt } 3 \text { A, Y-27632 (for single } \\
\text { cell culture in the first } 2 \\
\text { days) }\end{array}$ & Matrigel & $\begin{array}{l}\text { Withdrawal of } \\
\text { Wnt3A }\end{array}$ & (Sato et al., 2011) \\
\hline Endoderm & Colon & Human & $\begin{array}{l}\text { EGF, Noggin, R-spondin 1, } \\
\text { Wnt3A, gastrin, } \\
\text { nicotinamide, A-83-01, } \\
\text { SB202190 }\end{array}$ & Matrigel & $\begin{array}{l}\text { Withdrawal of } \\
\text { Wnt3A, } \\
\text { nicotinamide and } \\
\text { SB202190 }\end{array}$ & (Sato et al., 2011) \\
\hline Endoderm & Stomach & Mouse & $\begin{array}{l}\text { EGF, Noggin, R-spondin 1, } \\
\text { Wnt3A, gastrin, FGF10, Y- } \\
27632 \text { (for single cell } \\
\text { culture in the first } 2 \text { days), }\end{array}$ & Matrigel & Wnt 3 A reduction & $\begin{array}{l}\text { (Barker et al., } \\
\text { 2010) }\end{array}$ \\
\hline Endoderm & Stomach & Human & $\begin{array}{l}\text { EGF, Noggin conditioned } \\
\text { medium, R-spondin } 1 \\
\text { conditioned medium, Wnt } \\
\text { conditioned medium, } \\
\text { gastrin, FGF10, A-83-01, } \\
\text { nicotinamide (for single cell } \\
\text { culture), Y-27632 (for single } \\
\text { cell culture) }\end{array}$ & Matrigel & $\begin{array}{l}\text { Nicotinamide for } \\
\text { gland-type } \\
\text { organoids; } \\
\text { Withdrawal of Wnt } \\
\text { for pit-type } \\
\text { organoids }\end{array}$ & $\begin{array}{l}\text { (Bartfeld et al., } \\
\text { 2015) }\end{array}$ \\
\hline Endoderm & Liver & Mouse & $\begin{array}{l}\text { Gastrin, EGF, R-spondin 1, } \\
\text { FGF10, nicotinamide, HGF, } \\
\text { Y-27632 (for single cell } \\
\text { culture in the first } 4 \text { days), } \\
\text { Noggin and Wnt3a (for the } \\
\text { first } 4 \text { days) }\end{array}$ & Matrigel & $\begin{array}{l}\text { Withdrawal of R- } \\
\text { spondin 1, HGF } \\
\text { and nicotinamide } \\
\text { and addition of } \\
\text { EGF, FGF10, A- } \\
\text { 83-01, DATP and } \\
\text { dexamethasone }\end{array}$ & $\begin{array}{l}\text { (Huch et al., } \\
\text { 2013b) }\end{array}$ \\
\hline Endoderm & Liver & Human & $\begin{array}{l}\text { Gastrin, EGF, R-spondin } 1 \\
\text { conditioned medium, } \\
\text { FGF10, nicotinamide, HGF, } \\
\text { A-83-01, Forskolin (a cAMP } \\
\text { pathway agonist); For the } \\
\text { first } 3 \text { days also including } \\
\text { Y-27632, Noggin and Wnt } \\
\text { conditioned medium }\end{array}$ & Matrigel & $\begin{array}{l}\text { First BMP7 for 2-4 } \\
\text { days and then the } \\
\text { withdrawal of N- } \\
\text { acetylcysteine, R- } \\
\text { spondin 1, FGF10, } \\
\text { nicotinamide and } \\
\text { Forskolin and } \\
\text { addition of FGF19, } \\
\text { DAPT and } \\
\text { dexamethasone }\end{array}$ & $\begin{array}{l}\text { (Huch et al., } \\
2015)\end{array}$ \\
\hline Endoderm & Pancreas & Mouse & $\begin{array}{l}\text { Gastrin, EGF, R-spondin } 1 \text {, } \\
\text { Noggin, FGF10, } \\
\text { nicotinamide, Y-27632 (for } \\
\text { single cell culture in the first } \\
4 \text { days) }\end{array}$ & Matrigel & $\begin{array}{l}\text { In suspension } \\
0.2 \% \text { FBS, Activin } \\
\text { A for } 3 \text { days, then } \\
\text { with indolactam-V, } \\
\text { FGF } 10,2 \% \text { FBS } \\
\text { for } 4-5 \text { days, and } \\
\text { then with B27, } \\
\text { Noggin, retinoic }\end{array}$ & $\begin{array}{l}\text { (Huch et al., } \\
\text { 2013a) }\end{array}$ \\
\hline
\end{tabular}




\begin{tabular}{|c|c|c|c|c|c|c|}
\hline & & & & & $\begin{array}{l}\text { acid, KAAD- } \\
\text { cyclopamine for } 6 \\
\text { days, finally with } \\
\text { B27 and DBZ for } \\
2-4 \text { days before in } \\
\text { vivo } \\
\text { transplantation in } \\
\text { kidney capsule }\end{array}$ & \\
\hline Endoderm & Pancreas & Mouse & $\begin{array}{l}\text { Gastrin, EGF, R-spondin 1, } \\
\text { Noggin, FGF10, } \\
\text { nicotinamide, Y-27632 (for } \\
\text { single cell culture in the first } \\
4 \text { days) }\end{array}$ & Matrigel & & (Boj et al., 2015) \\
\hline Endoderm & Pancreas & Human & $\begin{array}{l}\text { EGF, R-spondin } 1 \\
\text { conditioned medium, Wnt3a } \\
\text { conditioned medium, } \\
\text { Noggin conditioned } \\
\text { medium, gastrin, FGF10, } \\
\text { nicotinamide, A-83-01, } \\
\text { prostaglandin E2 }\end{array}$ & Matrigel & & (Boj et al., 2015) \\
\hline Endoderm & Lung & Human & $\begin{array}{l}10 \% \text { FCS, hydrocortisone, } \\
\text { insulin, transferrin, } \\
\text { triiodothyronine, } \\
\text { choleragen, adenine, EGF }\end{array}$ & $\begin{array}{l}\text { 3T3-J2 } \\
\text { feeder }\end{array}$ & $\begin{array}{l}\text { Self-assembly or } \\
\text { Matrigel with } \\
\text { retinoic acid, } \\
\text { cholera toxin, } \\
\text { knockout serum } \\
\text { replacement }\end{array}$ & $\begin{array}{l}\text { (Kumar et al., } \\
\text { 2011) }\end{array}$ \\
\hline Endoderm & Lung & Mouse & $\begin{array}{l}\text { Insulin, transferrin, cholera } \\
\text { toxin, EGF, bovine pituitary } \\
\text { extract, } 5 \% \text { FBS, retinoic } \\
\text { acid }\end{array}$ & $\begin{array}{l}\text { Matrigel } \\
\text { at air- } \\
\text { liquid } \\
\text { interface }\end{array}$ & $\begin{array}{l}\text { Coculture with } \\
\text { primary PDGFRa' } \\
\text { lung stromal cells }\end{array}$ & $\begin{array}{l}\text { (Barkauskas et } \\
\text { al., 2013) }\end{array}$ \\
\hline Endoderm & Prostate & $\begin{array}{l}\text { Mouse/h } \\
\text { uman }\end{array}$ & $\begin{array}{l}\text { EGF, Y-27632, } 5 \% \\
\text { Matrigel, } 5 \% \text { charcoal- } \\
\text { stripped FBS, DHT }\end{array}$ & Flotation & $\begin{array}{l}\text { Same as } \\
\text { expansion } \\
\text { condition }\end{array}$ & $\begin{array}{l}\text { (Chua et al., } \\
\text { 2014) }\end{array}$ \\
\hline Endoderm & Prostate & Mouse & $\begin{array}{l}\text { EGF, Noggin, R-spondin, } \\
\text { A-83-01, DHT }\end{array}$ & Matrigel & $\begin{array}{l}\text { Same as } \\
\text { expansion } \\
\text { condition }\end{array}$ & $\begin{array}{l}\text { (Karthaus et al., } \\
\text { 2014) }\end{array}$ \\
\hline Endoderm & Prostate & Human & $\begin{array}{l}\text { EGF, Noggin, R-spondin, } \\
\text { A-83-01, DHT, FGF10, } \\
\text { FGF2, prostaglandin E2, } \\
\text { nicotinamide, SB202190 }\end{array}$ & Matrigel & $\begin{array}{l}\text { Same as } \\
\text { expansion } \\
\text { condition }\end{array}$ & $\begin{array}{l}\text { (Karthaus et al., } \\
\text { 2014) }\end{array}$ \\
\hline Ectoderm & $\begin{array}{l}\text { Mammary } \\
\text { gland }\end{array}$ & Mouse & $\begin{array}{l}\text { Insulin, hydrocortisone, } \\
\text { prolactin, 1\% FCS }\end{array}$ & Matrigel & $\begin{array}{l}\text { Same as } \\
\text { expansion } \\
\text { condition }\end{array}$ & $\begin{array}{l}\text { (Shackleton et al., } \\
\text { 2006) }\end{array}$ \\
\hline Ectoderm & $\begin{array}{l}\text { Mammary } \\
\text { gland }\end{array}$ & Mouse & $\begin{array}{l}\text { Hydrocortisone, insulin, } \\
\text { EGF, FGF2, FGF10, } \\
\text { Wnt3A, heparin, R-spondin } \\
\text { 2, Y-27632 }\end{array}$ & $\begin{array}{l}\text { Baseme } \\
\text { nt } \\
\text { membra } \\
\text { ne } \\
\text { extract }\end{array}$ & $\begin{array}{l}\text { Same as } \\
\text { expansion } \\
\text { condition }\end{array}$ & $\begin{array}{l}\text { (Jamieson et al., } \\
2016 \text { ) }\end{array}$ \\
\hline Ectoderm & Retina & Mouse & With or without FGF2 & $\begin{array}{l}\text { Suspensi } \\
\text { on }\end{array}$ & $\begin{array}{l}\text { On poly-L- } \\
\text { ornithine-coated } \\
\text { glass in EGF } \\
\text { containing serum- } \\
\text { free medium }\end{array}$ & $\begin{array}{l}\text { (Tropepe et al., } \\
\text { 2000) }\end{array}$ \\
\hline Ectoderm & $\begin{array}{l}\text { Salivary } \\
\text { gland }\end{array}$ & Mouse & $\begin{array}{l}\text { EGF, FGF2, insulin, } \\
\text { dexamethasone, Y-27632 }\end{array}$ & Matrigel & $\begin{array}{l}\text { Intact spheres in } \\
\text { collagen-Matrigel } \\
\text { mixture }(4: 6) \text { and }\end{array}$ & $\begin{array}{l}\text { (Nanduri et al., } \\
\text { 2014) }\end{array}$ \\
\hline
\end{tabular}


$10 \%$ FCS

containing medium

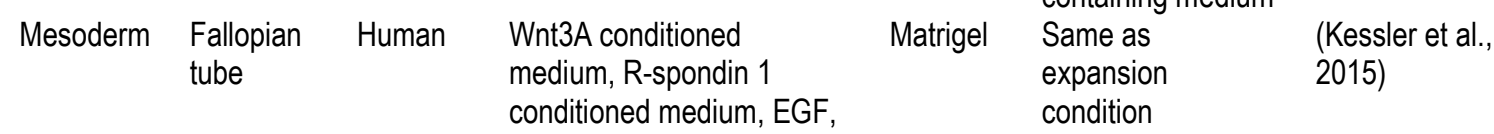

noggin, FGF10,

nicotinamide, Y-27632,

SB431542

1711 